\title{
Papers
}

of the

East-West

Population Institute

No. $60-\mathrm{G}$

CURRENT

STUDIES

ON

THE VALUE

OF CHILDREN

\section{The \\ old-age economic security value of children in the Philippines and Taiwan}

Susan De Vos

王 
PAPERS OF THE EAST-WEST POPULATION INSTITUTE, published about eight times a year, facilitate early dissemination of research findings and state-of-the-art essays on the demography of Asia, the Pacific, and the United States. Annual subscription rate, $\$ 12$.

NOTE TO CONTRIBUTORS: The Population Institute considers unsolicited as well as commissioned manuscripts for the Paper Series. Appropriate topics are population estimation and analysis, causes and consequences of demographic behavior, urbanization and population distribution, and population policies and programs. All manuscripts are reviewed. In selecting manuscripts for publication, the Institute considers quality of scholarship and usefulness to public officials and other professionals in the field of population; it also seeks contributions reflecting diverse cultural and disciplinary perspectives on population. The series can accommodate articles not necessarily suited for journals because of unusual length or treatment of subject. All copy must be typed double-spaced. For additional information on manuscript preparation, write to the Publications Office, East-West Center.

\section{OTHER SERIAL PUBLICATIONS OF THE EAST-WEST POPULATION INSTITUTE:}

Working Papers are circulated for comment and to inform interested colleagues about work in progress at the East-West Population Institute. They are intended to complement evidence of completed work as reflected in Papers of the EastWest Population Institute and the Reprint Series. \$1 per copy.

Reprint Series brings selected articles originating from Institute research but published elsewhere to the attention of population specialists who might not otherwise see them. Single copies available upon request.

Asian and Pacific Census Forum is a quarterly periodical reporting on census, vital registration, and population survey activities in Asia and the Pacific. The Forum contains technical articles on a range of topics related to demographic measurement, and reviews of new publications in the field. Issued in August, November, February, and May. Annual subscription rate, $\$ 5$.

Serial publications except Working Papers are available without charge to libraries serving population specialists and to professionals and scholars in the field of population. Requests describing the nature of the research or program and the intended use of the publications should be addressed to the Publications Office of the Institute. 
CURRENT

STUDIES

ON

THE VALUE

OF CHILDREN

\author{
The \\ old-age \\ economic \\ security \\ value \\ of children \\ in the \\ Philippines \\ and Taiwan
}

Susan De Vos

Number 60-G • March 1984

PAPERS OF THE EAST-WEST POPULATION INSTITUTE 
SUSAN DE VOS is Postdoctoral Trainee at the Center for Demography and Ecology, University of Wisconsin-Madison.

Library of Congress Cataloging in Publication Data

De Vos, Susan, 1953-

The old-age economic security value of children in the Philippines and Taiwan.

(Papers of the East-West Population Institute, ISSN 732-0531; 60-G)

"Based on the author's Ph.D. dissertation in sociology ' at the University of Michigan"-Pref.

Bibliography: $p$.

1. Family size-Economic aspects-Philippines. 2. Family size-Economic aspects-Taiwan. 3. ParentsPhilippines-Attitudes. 4. Parents-Taiwan-Attitudes. 5. Sex of children, Parental preferences forPhilippines. 6. Sex of children, Parental preferences for-Taiwan. I. Title. HQ762.P6D4 $1984 \quad 304.6^{\prime} 34^{\prime} 09599 \quad 84-6081$ ISBN 0-86638-056-6 


\section{CONTENTS}

Preface vii

Abstract 1

Focus of the study $\quad 1$

The data 5

Findings 7

Conclusion 54

Appendix $\quad 63$

References 67 



\section{TABLES AND FIGURES}

Tables

1. Percentage of VOC respondents who mentioned old-age support in response to open-ended questions about the advantages of having children: Philippines (1975) and Taiwan (1976) 8

2. Percentage distribution of responses to closed-ended questions about the old-age support value of children: Philippines (1975) and Taiwan (1976) 10

3. Support expectations by selected socioeconomic characteristics: Philippines (1975) and Taiwan (1976) 12

4. Support expectations by selected attitude measures: Philippines (1975) and Taiwan (1976) 18

5. Support expectations by attitude measures used in Taiwan only (1976) 19

6. Logistic effects of socioeconomic and attitude factors on none/ some support expectations: Philippines (1975) and Taiwan (1976) 23

7. Transformed logit coefficients for less/great support expectations on socioeconomic and attitude variables: Philippines (1975) and Taiwan (1976) 25

8. Average preferred fertility by support expectations: Philippines (1975) and Taiwan (1976) 28

9. Multiple regression coefficients for effect of amount of expected reliance on children for financial support when old on selected measures of fertility preferences: Philippines (1975) and Taiwan (1976) 31

10. Logistic effect of expecting to rely on children "a great deal" versus "a little" on the odds of whether respondent wants an additional child, by parity: Philippines (1975) and Taiwan (1976) 34 
11. Multiple regression contrast of great/lit tle support expectations on Coombs IN by selected socioeconomic characteristics: Philippines (1975) and Taiwan (1976) 36.

12. Multiple regression contrast of great/little support expectations on Coombs IN by selected social-psychological orientations: Philippines (1975) and Taiwan (1976) 38

13. Multiple regression contrast of great/little support expectations on Coombs IN by selected family orientations: Philippines (1975) and Taiwan (1976) 40

14. Percentage of VOC respondents who expected to rely on sons and daughters for financial support when old: Philippines (1975) and Taiwan (1976) 43

15. Percentage distribution of individual sex preference (Coombs IS): Philippines (1975) and Taiwan (1976) 44

16. Sex preference by amount of expected reliance on sons when old: Philippines (1975) and Taiwan (1976) 45

17. Estimated net relationship between expected reliance and son preference: Taiwan (1976) 48

18. Estimated net relationship between expected reliance and son preference within selected socioeconomic strata: Taiwan (1976) 50

19. Effect of a hypothetical government pension on the relationship between expected reliance and son preference within selected socioeconomic strata: Taiwan (1976) 53

Figures

1. Hypothetical relationship between expected reliance and son preference 47

2. Hypothetical relationship between expected reliance and son preference at different stages in the modernization process 


\section{PREFACE}

This paper is based on the author's Ph. D. dissertation in sociology at the University of Michigan. Research was conducted at the University of Michigan's Population Studies Center under a predoctoral training grant from the National Institutes of Health (NIH). The author is grateful to Ronald Freedman, Lois Hoffman, Martin Whyte, and Mayer Zald for their advice and assistance. Rodolfo Bulatao and Te-Hsiung Sun kindly granted access to the Philippine and Taiwan Value of Children data. Fred Arnold and James Fawcett were most encouraging at an early stage of the project. The author gratefully acknowledges the comments of Rodolfo Bulatao, Alice Clark, Scott Grosse, James Fawcett, K. Radhakrishna Murty, and Lynn Wallisch on earlier drafts of the paper. Sandra Ward provided excellent editorial assistance. Sharon Kennedy, Janice Deneen, and Rochelle Reimer assisted in the preparation of the final manuscript. The revision was carried out under NIH postdoctoral training grant 5T32 HD07014 at the University of Wisconsin's Center for Demography and Eçology. Core support to the Center from the National Institute of Child Heal th and Human Development is also gratefully acknowledged. 



\begin{abstract}
This paper compares individuals' perceptions of the value of children as economic security in old age in the Philippines and Taiwan. Drawing upon nationally representative, cross-societally comparable dat a from Value of Children surveys conducted in 1975 and 1976. it also examines the relation between children 's economic security value and respondents' socioeconomic characteristics, attitudes, family-size preferences, and sex preferences. Respondents were wives of childbearing age.

Whereas most industrialized countries have developed specific social institutions that provide economic support to dependent elderly people, this function has been performed by the family in less industrialized countries. In countries undergoing development, such as Taiwan and the Philippines, the Value of Children study design assumed that socioeconomic status would influence respondents' perceptions of children's values, and that better educated and well-to-do wives would have more "modern" value orientations than less educated, lower-income women.

The findings reported here reveal that, in both the Philippines and Taiwan, expected reliance on children for financial support in old age ("support expectations") was substantial, but it was less prevalent among respondents in higher socioeconumic strata and those with more "modern" attitudes than among others. Multivariate analysis found socioeconomic characteristics and several attitudes to be independent predictors of support expectations.

Support expectations were found to affect fertility preferences, particularly the desire for four or more children, even after many potentially explanatory factors were controlled for. Support expectations from sons were found to be related to sex preferences in Taiwan but not in the Philippines, perhaps because Philippine women expected similar levels of support from both sons and daughters whereas women in Taiwan expected to rely primarily on sons.
\end{abstract}

\title{
FÓCUS OF THE STUDY
}

THE ECONOMIC SUPPORT of dependent elderly people is a central component in the relationship between generations and has important welfare and demographic consequences. In traditional societies, the elderly are expected to rely primarily on their families for economic and emotional support (Simmons, 1960: Cowgill and Holmes, 1972). If family support mechanisms fail, community help may or may not be forthcoming. In modern societies, special institutions perform at least some of the economic support function (Barnes, 1952). Elderly 
people expect to rely on the working-age population at large for economic support. ${ }^{1}$

This study focuses on support expectations in the Philippines and Taiwan. Both societies are experiencing economic growth and are developing new ways of organizing work and welfare. At the same time, some segments of each society adhere to traditional modes of organization and interaction more than others. The incipient development of pension schemes is a case in point. Pensions are often available only to an urban elite who work for bureaucratized employers or who are organized into labor groups (Vreeland et al., 1979; Djang, 1977). This elite tends to be better educated and to consume more modern goods such as motorcycles, refrigerators, and televisions than other groups. On the other extreme are rural people, who organize their work according to more traditional family, patron, or community patterns, and who have less access to secondary or higher education, mass media, or modern consumer durables. But at present levels of pension benefits, where such benefits are available at all, they are still less than what is necessary to attain financial self-sufficiency in old age. In the mid-1970s most people in the Philippines and Taiwan expected to rely at least a little on children for financial support when old (Bulatao, 1975; Wu, 1977; Arnold et al., 1975).

The study investigates not only the kinds of support expectations respondents in the Philippines and Taiwan had from children, but also why their expectations varied. The speculated answer is that people with different expectations are associated with different modes of work and welfare organization, and that they have different socialpsychological orientations affecting their feelings of personal efficacy and attitudes toward self-sufficiency in old age. Unfortunately, the study does not have information about respondents' expected pension benefits, but an examination of differences in their expectations from children may provide a clue to the possible determinants of their expectations.

The study also examines a possible relationship between expected

1. "Traditional" and "modern" are of course ideal typical concepts, and one may expect considerable diversity among traditional or modern societies. The meaning of "transitional" or "developing" in this context may be confusing since most societies are probably in transition most of the time and may in fact be creating new traditions. Yet how else can one speak of change in the myriad facets of society that have coincided with the technological and economic innovations of the last several hundred years? (See O'Connell, 1976.) 
reliance on children for support when old and fertility preferences. Demographers speculate that, in many developing countries, where most people do not have pensions or savings, they find greatest old-age insurance in their children (Neher, 1971: Willis, 1981; see also Notestein, 1945: Lorimer, 1954: Caldwell, 1982). If children tend to pool their resources to care for elderly parents, having more children may result in more resources. More children may also insure that at least one child will care for aging parents (Polgar, 1971 ; Jones, 1977).

Past research has documented that most parents in developing countries expect to rely on children for financial support when old (Bulatao, 1979a, 1979b; Kagitcibasi, 1982), although the extent to which this expectation is realized is an open question (Vlassoff.and Vlassoff, 1980). It is also unclear whether people prefer large families because of old-age support considerations (Mueller, 1976: Coombs, 1980). Few studies have explored the connection between old-age security considerations and desired family size after controlling for other factors. One exception is a recently reported study by Vlassoff (1982), which found such a positive relationship among more traditional men only, in a village near Poona, India.

Also of interest is the relationship between expected reliance on sons for financial support in old age and an individual's sex preferences, especially in Taiwan, where son preference is strong. Demographers and family scholars have'speculated that old-age support considerations may be an important correlate, if not structural support, for the preference for sons found in many parts of the world (Williamson, 1976).

Empirical support for the notion has been limited to traditionally patrilineal societies and has suffered from potentially serious data problems. For instance, Poffenberger and Poffenberger (1973) found an association between old-age support considerations and a desire for sons in India, but they did not control for other important factors that are probably related to support expectations and son preference, which could cause a spurious relation. Williamson (1976) used multivariate analysis to explore the determinants of son preference in rural Taiwan, but she did not investigate specific degrees of son preference or the nature of the relationship between expected reliance on children in old age and son preference among different social sectors. Furthermore, she and other researchers have had difficulty with measuring sex preferences independently from family-size desires. The 
present analysis extends previous work by addressing the relationship in two dissimilar societies, by examining the situation in the Philippines and in different sectors of Taiwan, and by using a measure of sex preferences that is theoretically independent from fertility preferences (Coombs, 1975).

The issue of old-age support expectations has policy significance. If parents do not expect to rely on children financially, they probably have a greater demand for nonfamilial welfare arrangements. If the expected old-age economic security value of children helps determine fertility preferences, security substitutes for children could possibly decrease the demand for children. If the security value of sons is a determinant of son preference, then an equalization of the perceived security value of sons and daughters could possibly affect people's sex preferences. This last hypothesis has probable consequences for the health and welfare of females (see Chen et al., 1981). Additionally, son preference may have important consequences for contraceptive use (Freedman and Coombs, 1974) and fertility (C. B. Park, 1978).

The reason why this study examines expected rather than actual or preferred reliance on children is that expectations address the future and may influence current preferences or future behavior. In contrast, present behavior may be based on ideas formulated in the past, and on needs and obligations that may not exist in the future.

A comparison of support expectations in the Philippines and Taiwan helps to speak to the generality of ideas concerning expected reliance on children for support in old age in developing countries. The two countries are close geographically but differ markedly in social and cultural background, as well as in recent rates of economic growth.

For instance, the traditional family in the Philippines is quite different from that in Taiwan. The traditional Filipino family is bilineal; people expect both sons and daughters to help parents in old age, and they tend to prefer a balanced number of sons and daughters. Interdependencies may extend beyond the nuclear or stem family to neighbors or other kinsmen. Child adoption by kinsmen occurs occasionally, and "kinship" ties may be established or strengthened through godparenting or coparenting ( $\mathrm{Yu}$ and Liu, 1980). Most people may expect financial assistance from their children when old, but not having children does not necessarily leave one without care since responsibility for the elderly may be shared among community and family 
members. Furthermore, there may be little reason to prefer sons out of old-age considerations since old-age support has been expected from daughters as wcll as sons. In contrast, the traditional Chinese family is patrilineal, and responsibility for elderly parents is shared by sons only. Interdependencies are confined to the stem family, residually to brothers of the same father. Since sons usually cannot be adopted but must be born into each family, one might expect there to be strong links between support expectations, family-size desires, and son preference.

In addition, nontraditional ideas and behavior have probably permeated all sectors of society to a greater extent in the Philippines than in Taiwan. The Philippines was Christianized and colonized by the Spanish for over 300 years, and then colonized by America for a half century (Vreeland et al., 1979). In contrast, Taiwan's exposure to nontraditional ideas has been largely confined to this century and for the most part to the period after World War II (Chaffee et al., 1969). The Philippines has a higher level of educational attainment than most other East Asian societies. In the present study of women of childbearing age, over 25 percent of the Philippine sample had attended at least senior high school compared with less than 9 percent of the Taiwan sample.

It is true that Taiwan is economically more advanced than the Philippines. Twenty-two percent of the work force was in the primary sector in 1980 compared with 53 percent in the Philippines (Far Eastern Economic Review, 1981). Taiwan's GNP per capita in 1977 was estimated at US\$1, 180, compared with the Philippines's US\$450 (World Bank, 1980). The proportion of the labor force in agriculture in 1970 is estimated to have been 35 percent in the Philippines and 55 percent in Taiwan (World Bank, 1980). However, Taiwan's development appears too recent to be reflected in more modern attitudes in all but the youngest and socially elite groups. Although family-related attitudes appear to be changing in Taiwan at a relatively rapid rate, as of 1976 they remained fairly traditional among the old and less advantaged population (Coombs and Sun, 1980).

\section{THE DATA}

This study uses nationally representative survey data of women of childbearing age in the Philippines and Taiwan, gathered as part of the 
cross-national Value of Children (VOC) Study. ${ }^{2}$ To shed light on the psychological, social, and economic reasons why people have children, the study collected information on individuals' perceptions of the satisfactions and costs of children. The VOC survey questions, both open-ended and closed-ended, were well suited for an investigation of the old-age economic security value of children. They enquired about respondents' expectations of help from children, emotional and social values they attached to children, husband and wife decision making, religiosity, wife's work experience, and other family factors that should be controlled for when investigating a possible relationship between a respondent's expected reliance on children or sons, son preference, and fertility. The study also measured feelings of personal efficacy, exposure to mass media, and the possession of modern objects. The data set includes common measures of socioeconomic and demographic characteristics, as well as less common ones such as the Coombs IN and Coombs IS scales, which measure preferences for family size and gender composition, respectively.

Two rounds of in-depth interviews were conducted in the early and middle 1970s. Pretest surveys of about 400 respondents each were conducted in six countries, including the Philippines and Taiwan. ${ }^{3}$ In the pretests, approximately equal numbers of urban middle-class, urban lower-class, and rural respondents were selected to maximize comparability between social groups. Respondents were cohabiting couples with at least one child. Wives were 20-34 years of age; husbands were 20-44. National representation was not a goal.

In the final round of surveys, improved question wording, national representation, and comparability across societies were important goals. National probability samples of 1,691 wives of childbearing age and a subset of their husbands were in terviewed in the Philippines

2. Coordinators of the VOC Study were Fred Arnold, Rodolfo A. Bulatao, and James T. Fawcett at the East-West Population Institute. The co-investigators were Masri Singarimbun and Russell K. Darroch (Indonesia); Sung Jin Lee (Republic of Korea); Rodolfo A. Bulatao (Philippines); Peter S.J. Chen, Betty Jamie Chung, and Eddie Kuo (Singapore); Te-Hsiung Sun and Tsong-Shien Wu (Taiwan); Chalio Buripakdi, Nibhon Debavalya, and Visid Prachuabmoh (Thailand); Cigdem Kagitcibasi (Turkey); and Lois W. Hoffman, Fred Arnold, and James T. Fawcett (United States).

3. The pretest was conducted in Taiwan, Japan, the Republic of Korea, the Philippines, Thailand, and the United States (Hawaii). See Amold et al. (1975) for a comparative overview of the pretest results. See also Bulatao (1975) for the Philippine results and $W u(1977)$ for the Taiwan results. 
between September and December 1975, and 2,217 wives and a subset of their husbands and mothers-in-law were interviewed in Taiwan between January and April 1976.

The present study uses the wives' data from the two nationally representative surveys. In the Philippines the sampling frame was stratified into Manila and other areas. In Taiwan, townships were stratified on the basis of type of area, educational level, and total fertility rate. Women were selected from household registration lists. The response rate for wives in the Philippines was 91 percent, in Taiwan 93 percent.

The core questionnaire was originally written in English and then translated into the languages of the study areas. Questions were translated back into English to insure that the meaning had been retained in translation. Consistency checks were made during the fieldwork and coding stages.

Most of the Philippine interviewers were female college or university students. In Taiwan the women interviewers had at least a high-school education, were between 23 and 50 years old, and in most cases had participated in previous surveys. (For more information on the VOC project, see Bulatao, 1979b; De Vos, 1982; and VOC Technical Notes, available upon request from the East-West Population Institute.)

\section{FINDINGS}

\section{Major differences between the Philippines and Taiwan}

The VOC survey' asked respondents several open-ended questions about the advantages of having children and of having sons and daughters. Help in old age was mentioned as an advantage of having children by over 40 percent of the Philippine sample and by 29 percent of the Taiwan sample (Table 1). Less than 10 percent, however, volunteered old-age support as a reason to have a daughter. Moreover, lack of expectation of help from children in old age was rarely given as a reason for not wanting fewer children than respondents had said they desired to have.

One major difference between the Philippines and Taiwan was in responses to an open-ended question about the most important reasons for wanting a son. In the Philippines only 4 percent of the respondents mentioned old-age support. In Taiwan nearlý half of all respondents mentioned it (Table 1 ).

A second major difference in responses to open-ended questions on 
TABLE 1. Percentage of VOC respondents who mentioned old-age support in response to open-ended questions about the advantages of having children: Philippines (1975) and Taiwan (1976)

Question and order in which

old-age support was mentioned

Philippines

Taiwan

What are some of the advantages or good things about having children, compared to not having children at all?

1st mention

2nd mention

3rd mention

All mentions

What are some of the reasons why you would prefer not to have fewer than children ${ }^{\circ}$

1st mention

2nd mention 1

Both mentions

What are the most important reasons for wanting a daughter?

1st mention

2nd mention

Both mentions

$\begin{array}{ll}2 & 6 \\ 6 & 3 \\ 8 & 9\end{array}$

What are the most important reasons for wanting a son?

1st mention

2nd mention

a. Interviewer completed question by mentioning the number of children the respondent had earlier said she wanted to have.

the advantages of having children was that Filipinas mentioned both emotional and economic security advantages of children whereas Taiwanese seem to have mentioned economic security advantages only (figures not shown). This difference could be due to different coders' interpretations of similar responses or could represent true differences in Philippine and Taiwanese respondents' perceptions. In both countries there seemed to be little economic concern in responses to the question about the advantages of daughters.

Although responses to the open-ended questions on the advantages of children are informative, they have two major shortcomings in a 
study of this sort. First, the answers include both economic and emotional considerations, whereas the present study focuses on the economic security value of children only. Second, many respondents who do not independently mention old-age security as a reason to have children may still expect to rely on their children for support in old age.

VOC respondents were also asked several closed-ended questions on the importance of help in old age as a reason to have children (Table 2). In answer to the first, nine-tenths of the Philippine respondents and four-fifths of the Taiwanese affirmed that old-age dependency is a very important reason to have children. However, since almost everyone gave the same "very important" answer, the indicator has little variance either to be explained or to help explain anything else.

The second question asked whether being sure of having help in old age was a reason for wanting another child. Interestingly, such assurance was considered "very important" by most of the Philippine respondents but by fewer than half of the Taiwan respondents. This finding suggests that old-age considerations may have a greater effect on fertility preferences in the Philippines than in Taiwan-although, in Taiwan, the answers to the question were not related to whether respondents wanted an additional child. The question on help in old age did not specify economic help, and it explicitly drew a connection between old-age security and fertility for the respondent. It would have been preferable that no such connection existed in the question itself.

Fortunately, the VOC surveys contained other closed-ended questions on the perceived old-age value of sons and daughters that specified economic security but did not explicitly draw a connection between old-age security and fertility. There was a set of initial questions ("If you had sons/daughters, would you expect your sons/daughters to support you financially when you grow older?"), and follow-up probes ("Would you expect to rely on your sons/daughters a great deal for financial support when you grow old, or only a little?"). Answers to the initial and follow-up questions have been combined in Table 2. Responses of "no" to the initial question are coded as "none." "Yes" answers are differentiated by the amount specified in the answer to the follow-up question. The answers suggest, as did answers to the open-ended questions, that many women in both societies perceived children as having an old-age security value. This valuation appears 
TABLE 2. Percentage distribution of responses to closed-ended questions about the old-age support value of children: Philippines (1975) and Taiwan (1976)

\begin{tabular}{|c|c|c|}
\hline Question and response & Philippines & Taiwan \\
\hline \multicolumn{3}{|c|}{$\begin{array}{l}\text { Importance of having someone to depend on } \\
\text { when old as a reason for having a child }\end{array}$} \\
\hline Not important & 2 & 7 \\
\hline Somewhat important & 9 & 14 \\
\hline Very important & 89 & 79 \\
\hline \multicolumn{3}{|c|}{$\begin{array}{l}\text { Importance of being sure that you will have } \\
\text { someone to help you in old age as a reason } \\
\text { for wanting an additional child }\end{array}$} \\
\hline Not important & 10 & 47 \\
\hline Somewhat important & 12 & 15 \\
\hline Very important & 78 & 38 \\
\hline \multicolumn{3}{|c|}{ Amount of expected reliance on son $/ \mathrm{s}$} \\
\hline None & 14 & 13 \\
\hline A little & 54 & 34 \\
\hline A great deal & 32 & 53 \\
\hline \multicolumn{3}{|c|}{ Amount of expected reliance on daughter/s } \\
\hline None & 11 & 60 \\
\hline A little & 58 & 37 \\
\hline A great deal & 31 & 3 \\
\hline \multicolumn{3}{|c|}{ Amount of expected reliance on children ${ }^{a}$} \\
\hline None & 10 & 12 \\
\hline A little & 55 & 34 \\
\hline A great deat & 35 & 55 \\
\hline
\end{tabular}

8. Responses to this question are derived from responses to the two previous questions. Percentages represent respondents who expected to rely on daughters or sons not at all, somewhat, or a great deal.

fairly equal for sons and daughters in the Philippines but not in Taiwan. In Taiwan a majority ( 53 percent) of respondents expected to rely on sons a "great deal" for financial support when old, but only 3 percent expected to rely on daughters a great deal. In fact, a substantial majority did not expect to rely on their daughters at all.

Cognizant of this difference between the Philippines and Taiwan, I still wanted a measure of the old-age economic security value of children that could be used to compare the two countries. For this I combined responses to the separate questions on sons and daughters 
to form a single trichotomous variable called "support expectations" (last measure, Table 2). The "none" category contains responses of "no expectation" from either sons or daughters. The "great deal" category includes responses of individuals who expected to rely a great deal on either a son or a daughter. The middle category of "a little" contains the responses of people who expected to rely at least a little on a son or a daughter but did not expect to rely on either a great deal. ${ }^{4}$ This categorization ignores the major difference between the Philippines and Taiwan concerning expected reliance on daugh ters.

Although most respondents in the Philippines and Taiwan expected to rely on children for financial support in old age, they varied considerably in how much reliance they expected to place on their children. In the Philippines roughly a third of the sample expected to rely a great deal on their children whereas about half expected to rely only a little. In Taiwan the obverse was true. Roughly half expected to rely a great deal whereas roughly a third expected to rely only a little. In both countries about a tenth of the samples did not expect to rely on children at all.

That Filipinas expected to rely less than Taiwanese women on children for financial support when old held true across all age groups and various socioeconomic strata, including women with higher incomes, in urban areas, or with husbands in upper white-collar occupations (Table 3 ). Only among women with some high school or more education did Filipinas expect to rely on children more than did Taiwanese.

Several factors could account for this difference between the Philippines and Taiwan. Differences in traditional family and community structures, historical experiences, and economic development could all be important. Parental expectations appeared to be declining in Taiwan at a relatively rapid rate during the 1970 s (Coombs and Sun, 1981), and it is conceivable that they could have been declining in the Philippines as well. The two societies could exhibit different levels of expectations, and different variations in expectations, at some future point.

4. An analysis of the reliability of a similar question in a survey conducted in Taiwan in 1973 suggests that the VOC measure's reliability is on a par with that of other attitude measures. For a dichotomous measure, 86 percent of the respondents to a postenumeration survey provided the same response. When the possible variation is taken into consideration, a reliability index or reliability ratio can be calculated. With these measures, the reliability of the answers ranged between 42 and 47 , out of 100 (Coombs, 1977). 
TABLE 3. Support expectations by selected socioeconomic characteristics: Philippines (1975) and Taiwan (1976)

\begin{tabular}{|c|c|c|c|c|c|c|c|c|c|c|}
\hline \multirow[b]{3}{*}{ Characteristic } & \multicolumn{10}{|c|}{ Support expectations (\%) } \\
\hline & \multicolumn{5}{|c|}{ Philippines } & \multicolumn{5}{|c|}{ Taiwan } \\
\hline & None & Little & Great & $\mathrm{Phi}^{\mathrm{a}}$ & $(\mathrm{N})$ & None & Little & Great & $\mathrm{Phi}^{\mathrm{a}}$ & (N) \\
\hline Total & 10 & 55 & 35 & & $(1,672)$ & 12 & 34 & 55 & & $(2,217)$ \\
\hline Family income ${ }^{b}$ & & & & $.19^{*}$ & & & & & $.30^{*}$ & \\
\hline $10,000+$ & 33 & 54 & 13 & & $(80)$ & 32 & 43 & 25 & & (359) \\
\hline $4,500 / 5,000-9,999$ & 19 & 56 & 25 & & (259) & 12 & 42 & 46 & & (791) \\
\hline $2,000-4,499 / 3,000-4,999$ & 9 & 59 & 32 & & (575) & 4 & 28 & 67 & & (527) \\
\hline$<2,000 /<3,000$ & 6 & 48 & 46 & & (718) & 1 & 12 & 87 & & (195) \\
\hline Husband's occupation ${ }^{c}$ & & & & $.19^{*}$ & & & & & $.28^{*}$ & \\
\hline Upper white-collar & 21 & 64 & 14 & & (90) & 26 & 43 & 31 & & (539) \\
\hline Mid/low white-collar & 12 & 61 & 27 & & (316) & 17 & 41 & 42 & & (288) \\
\hline Upper blue-collar & na & na & na & & & 7 & 39 & 54 & & (536) \\
\hline Lower blue-collar & 8 & 62 & 30 & & $(530)$ & 5 & 33 & 62 & & (337) \\
\hline Farming/fishing & 5 & 49 & 46 & & $(667)$ & 3 & 16 & 81 & & (426) \\
\hline Education & & & & $.18^{\circ}$ & & & & & $.39^{*}$ & \\
\hline College & 29 & 32 & 19 & & $(145)$ & 69 & 29 & 2 & & (58) \\
\hline Senior high & 15 & 63 & 23 & & (219) & 47 & 46 & 7 & & (137) \\
\hline Junior high & 9 & 58 & 33 & & $(280)$ & 22 & 53 & 25 & & (215) \\
\hline Grammar & 8 & 55 & 37 & & (538) & 8 & 37 & 54 & & $(1,318)$ \\
\hline < grammar & 6 & 49 & 46 & & $(470)$ & 1 & 16 & 83 & & (489) \\
\hline
\end{tabular}


Residence $^{d}$

Urban barangay

Urban

Rural barangay/mix

Rural

Mass media exposure ${ }^{\mathrm{e}}$

Daily

Few times per week

Rarely

Never

Age

$<25$

25-29

$30-34$

35-39

40-45

$\begin{array}{rrr}14 & 68 & 18 \\ 10 & 63 & 27 \\ 8 & 67 & 25 \\ 6 & 51 & 43\end{array}$

8

25

43

.05

$12 \quad 54 \quad 34$

$10 \quad 56 \quad 37$

$9 \quad 55 \quad 36$

$6 \quad 52 \quad 42$

$8 \quad 55 \quad 37$

$9 \quad 56 \quad 35$

$13 \quad 50 \quad 38$

$10 \quad 58 \quad 32$

na na na

.05
$.15^{*}$

(193)

(349)

(159)

$\begin{array}{llll}(986) & 4 & 20 & 76\end{array}$

na

22

na

43

na

35

76

(417)

(957)

(827)

(852) $23 \quad 45 \quad 32$

$.24 *$

(651)

(180) $15 \quad 39 \quad 46$

(263)

(714)

(491) $7 \quad 32 \quad 61$

(589)

(143)

22

72

$.16^{*}$

(445)

na-not applicablé.

- $\chi^{2}$-significant at 05 if simple random sample.

a. A common measure of association. Phi can be used like $\chi^{2}$ but is not dependent on $N$ and can be used for asymetrically sized tables. I ts formula is $\left(\chi^{2} / N\right) \frac{1}{2}$.

b. Pesos per annum (Philippines): New Taiwan dollars (NTS) per month (Taiwan).

c. Upper white-collar occupations refer to professional, technical, administrative, executive, and managerial workers. In Taiwan lower whitecollar occupations refer to sales and clerical workers. In the Philippines lower white-collar and upper blue-collar occupations are combined into "middle" occupations. In Taiwan, upper blue-collar occupations refer to upper skilled workers and upper service workers. Lower blue-collar occupations refer to low-skilled or unskilled workers and lower service workers.

d. Barangay = town center in the Philippines. Barangav residents were divided into those with urban experience (urban barangay) and those with rural backgrounds (rural barangay). "Mix" refers to Taiwanese respondents who had lived in both rural and urban areas: most were urban residents at the time of the interviews.

e. Frequency of listening to radio or watching television. 


\section{Socioeconomic and attitude differentials}

The data reveal a pattern of expectations concerning reliance on children for financial support when old in both the Philippines and Taiwan, and the pattern requires examination. Why do some people expect to rely on their children a great deal whereas others only expect to rely on them a little? Are there systematic differences among socioeconomic groups or in attitudes that could help us predict an individual's support expectations?

People may have different expectations about supporting themselves without help from children. They may have different expectations concerning children's abilities to care for elderly parents. Or they could have different attitudes about relying on children for financial support when old. Such differences probably conform in part to differences among social groups. Yet it is difficult to discern to what degree such group differences are due to differential access to resources as opposed to differences of attitude. For instance, family income indicates economic resources, but it also implies different attitudes toward old-age living arrangements since people will have varying abilities to realize alternate lifestyles.

Other important social group indicators are education, husband's occupation, urban/rural residence, exposure to mass media, and age. Education (especially secondary education) requires resources and leads to more resources for the recipient in adulthood; but education may also cause exposure to new ideas, new ways of thinking, and preparation for participation in modern, nonfamilial institutions (Inkeles and Smith, 1974). Husband's occupation is an indicator of a family's financial resources, but it also places the family into a social group that shares common attitudes and access to information. Urban residents may have higher wages or greater economic opportunity than rural residents. They may also be more exposed to nontraditional ideas, modern goods, and nonfamilial economic institutions; and they may be less exposed to such traditional mechanisms of social control as community opinion or gossip. Exposure to mass media, which reflects ownership of radios or television sets, may influence attitudes. Inkeles and Smith (1974:174) caution, however, that the effect of mass media may depend on the economic constraints people face in adopting its messages.

Differences in age indicate different potential resources and different socialization experiences in rapidly changing societies. Younger 
people are often better equipped than the elderly to work in the modern, better-paying, industrial sector; and they may expect to be able to save for old age. They may also have less traditional attitudes toward the proper relationship between parents and children because they developed their ideas under more modern conditions.

Attitudes related to expected reliance on children in old age that are of interest are attitudes toward old age itself; attitudes toward children's responsibilities to their parents; perceptions of children's own attitudes toward caring for parents; general attitudes toward dependence, independence, and self-sufficiency; specific attitudes toward dependence in old age; and attitudes toward the government's role in providing old-age support. The comparative VOC data set has only a few of the potentially relevant variables, however. Several variables measure expectations of other kinds of help from both sons and daughters, and several measure personal efficacy. These are aggregated into two scales, labeled "other economic expectations" and "personal efficacy."

Additionally, the Taiwan survey asked attitude questions about young people's willingness to support parents and their capability of caring for parents, whether "modem" living makes it less convenient to live with parents, whether people should save for old age, and the best living arrangement for elderly parents.

In this section I examine the relationships between respondents' socioeconomic characteristics and attitudes on the one hand, and their support expectations on the other, in two steps. Before taking other factors into account, I consider bivariate differentials in support expectations. Then I examine the "independent" relationship between support expectations and each factor by controlling for other factors in a multivariate analysis. Several possible causal relationships are discussed.

\section{Birariate Differentials in Support Expectations}

In both the Philippines and Taiwan the amount of reliance on children had a clearly negative relation to family income. husband's occupational status, and respondent's education (Table 3 ). As these may be the most standard of socioeconomic indicators. this similarity between the two societies is important.

However, support expectations also varied between the countries in several important respects. For one, exposure to mass media had no 
relationship to support expectations in the Philippines but was negatively related to support expectations in Taiwan. I had expected a negative relationship in both countries, since mass media could transmit Western ideas of greater independence between parents and children. The reason for a discrepancy between countries is unclear. Perhaps many people with access to radio and television were financially constrained from accepting the media's messages in the Philippines but not in Taiwan. Perhaps the media did not transmit messages promoting greater intergenerational independence in the Philippines but did so in Taiwan. Or possibly the effect of the media had already reached its saturation point in the Philippines, whereas it still produced a differential in Taiwan because of that society's more recent exposure to some of the messages.

A second difference between countries was a null relation between age and support expectations in the Philippines but a positive relationship in Taiwan, older women there expecting to rely more on children for financial support than younger women. The null finding in the Philippines could be used to argue against the life-cycle hypothesis, which is that women come to expect more support as they age. The Taiwan result could be interpreted as a real difference between generations born before and after World War.II. Why this should have occurred in Taiwan but not the Philippines is, again, unclear. Perhaps the phenomenal economic growth that occurred in Taiwan after the war fostered a discontinuity between generations that did not occur in the Philippines, where economic growth was slower.

Third, socioeconomic differences in support expectations were less conspicuous in the Philippines than in Taiwan. For instance, the difference between women whose husbands were in white-collar occupations and those whose husbands were farm workers in their expectations of relying on children a "great deal" was 33 percentage points in the Philippines compared with 41 points in Taiwan (Table 3). This finding is consistent with the idea that the rate of economic development is positively associated with the size of differentials among socioeconomic groups since the rate of development had been lower in the Philippines. Other factors could have been at play here too.

The relationship between education and support expectations in Taiwan was striking, whereas it was similar to other differentials in the Philippines. In Taiwan 83 percent of respondents with less than a grammar school education expected to rely a "great deal" on children 
in old age, compared with only 7 percent of the respondents with a high school education and 2 percent of the respondents with a college education (Table 3 ). The corresponding figures in the Philippines were 46,23 , and 19 percent. It is possible that higher education alone produced the Taiwan effect. More probably, the relative newness of education for females caused the striking differential. Younger women were much better educated than older women in Taiwan, and higher education was still rare. Only 9 percent of the Taiwan sample had graduated from high school, compared with 22 percent of the Filipino sample.

I had expected urban residents to have lower support expectations than town or rural residents in both the Philippines and Taiwan. The urban/rural pattern in Taiwan fits expectations, but the pattern in the Philippines requires special notice. In the Philippines there was no smooth continuum from rural areas to settlements of ever-increasing size and density (Table 3). Barangay (town) residents with urban backgrounds had the lowest support expectations. Urban residents and barangay residents with rural backgrounds had similar and somewhat higher expectations. Rural residents had the highest expectations. Multivariate analysis revealed that this pattern is not explained by other socioeconomic characteristics or feelings of personal efficacy. Other researchers have also found indications that barangay residents, especially those with urban backgrounds, may be more modern than urban residents in their fertility characteristics (personal communication from Joseto Reoma, Population Studies Center, University of Michigan, October 1981).

Table 4 shows differential support expectations according to respondents' at titudes about other economic help from children and a composite psychological measure of personal efficacy. In both countries support expectations were positively related to expectations of other economic help from children and were negatively related to the measure of personal efficacy. Differences between countries were generally similar to those found for the socioeconomic differentials. In similar categories Filipinas expected to rely less on children than did Taiwanese. The range in expectations between categories tended to be greater in Taiwan than in the Philippines.

The Taiwan survey alone collected data on several attitudes that could be cross-classified with support expectations (Table 5). As expected, Taiwanese respondents who thought young people were less 
Support expectations (\%)

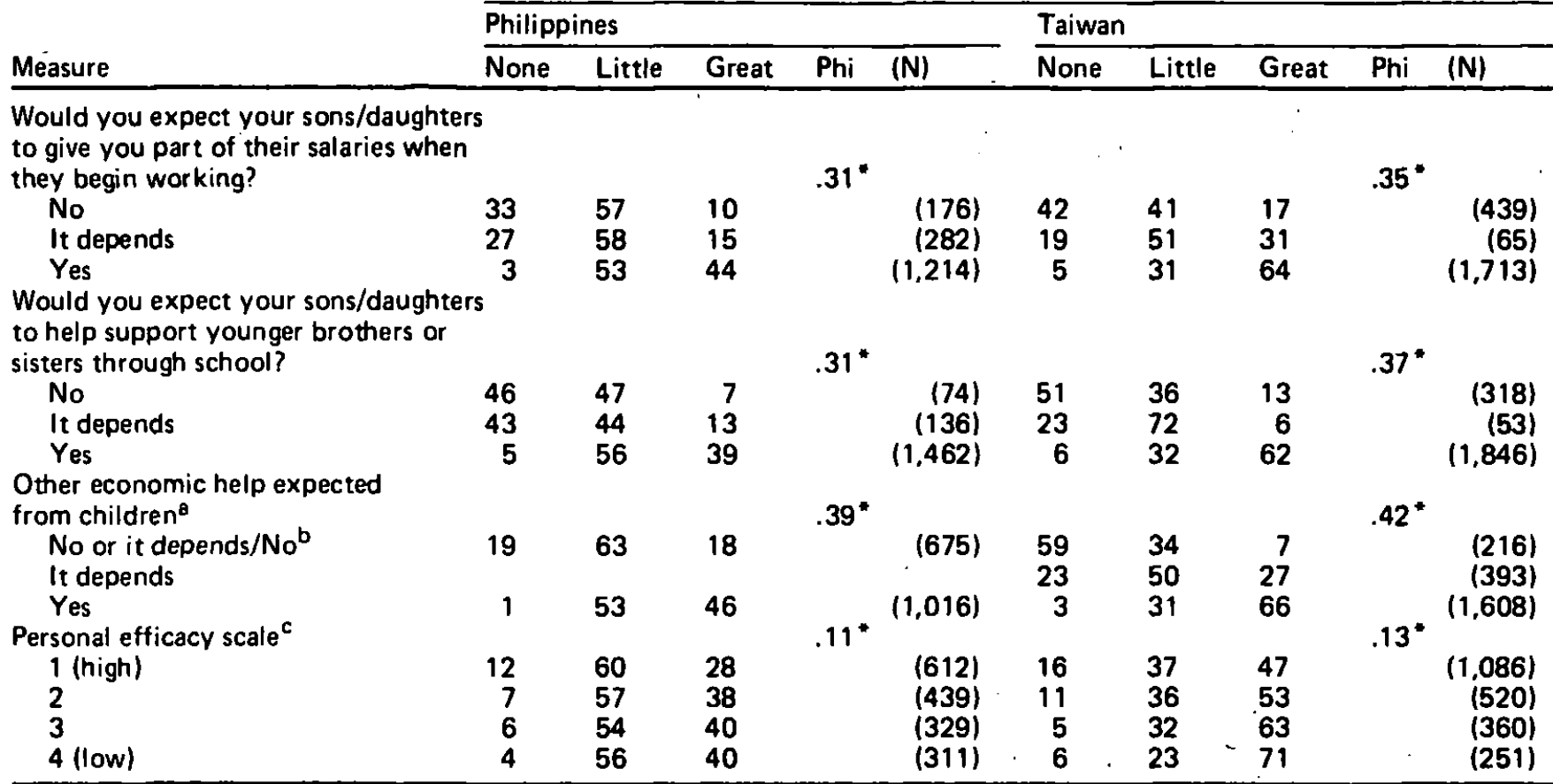

$\chi^{2}$ significant at .05 if sample were simple random sample.

a. Scaled veriable derived from a combination of responses to the first two variables (see Appendix).

b. In the Philippines the "no" and "it depends" categories were combined because there were so few responses in either category. In Taiwan the three-variable cotegory was retained.

c. Scaled variable derived from three attitude questions (see Appendix). 
TABLE 5. Support expectations by attitude measures used in Taiwan only (1976)

\begin{tabular}{llll}
\hline & & \multicolumn{3}{l}{ Support expectations (\%) } \\
\cline { 2 - 3 } Measure & None Little Great Phi (N) \\
\hline
\end{tabular}

Do you think young people nowadays are more willing or less to support parents in old age?

$\begin{array}{lrrr}\text { More } & 8 & 28 & 64 \\ \text { Same } & 10 & 31 & 59 \\ \text { Less } & 15 & 38 & 47\end{array}$

Do you think married young people, nowadays are less capable of supporting parents?

$\begin{array}{lrrr}\text { More } & 12 & 35 & 53 \\ \text { Same } & 10 & 31 & 59 \\ \text { Less } & 15 & 39 & 46\end{array}$

Do you think married young people nowadays are more willing to live with parents?

More
Same
Less

Do you agree with people who say it is inconvenient to live with parents in this modern industrial society?

Agree strongly
Agree slightly
Disagree slightly
Disagr ee strongly
you agree with people who think
that a person should save money when young so that he does not have to rely on his children for financial support when old?

$\begin{array}{rrr}6 & 26 & 68 \\ 5 & 29 & 66 \\ 15 & 37 & 48\end{array}$

$.13^{*}$

Agree strongly

Agree slightly

$\begin{array}{rrr}18 & 34 & 48 \\ 16 & 35 & 49 \\ 11 & 37 & 52 \\ 8 & 28 & 63\end{array}$

$.09^{*}$

Disagree slightly

Disagree strongly

$\begin{array}{rrr}25 & 41 & 34 \\ 10 & 41 & 49 \\ 1 & 21 & 78 \\ 1 & 8 & 91\end{array}$

(703) 
TABLE 5. (continued)

\begin{tabular}{|c|c|c|c|c|c|}
\hline \multirow[b]{2}{*}{ Measure } & \multicolumn{5}{|c|}{ Support expectations (\%) } \\
\hline & None & Little & Great & Phi & (N) \\
\hline \multicolumn{6}{|c|}{$\begin{array}{l}\text { To solve old-age living problem of } \\
\text { parents-in-law, with which statement } \\
\text { do you agree most strongly: } \\
\text { (a) Parents save money when young } \\
\text { and live alone off savings or pension } \\
\text { when old; (b) Parents live by them- } \\
\text { selves, but their children provide } \\
\text { financial support; (c) Parents live } \\
\text { with their children on rotational } \\
\text { basis; or they live with one child but } \\
\text { other children share parents' expenses. }\end{array}$} \\
\hline (a) & 32 & 46 & 22 & & (396) \\
\hline (b) & 17 & 46 & 37 & & (217) \\
\hline (c) & 7 & 30 & 63 & & $(1,596)$ \\
\hline
\end{tabular}

- $\chi^{2}$ significent at .05 if sample were simple rendom sample.

willing nowadays to support their parents were more likely than others to expect not to rely on children for financial support in old age. The picture was similar for women who answered that young married couples nowadays tend to be less capable of taking care of elderly parents or that young people are less willing to live with parents, or who strongly agreed that it is inconvenient for a married couple to live with parents in the "modern industrial" society. A fourth of the respondents who strongly agreed that it is "wise to save money while young so that one does not have to rely on children when old" (almost a third of the sample) had no expectations of relying on children for economic support. A third of the respondents who thought that the best living arrangement for old people was to live separately from children and be financially self-sufficient did not expect to rely on children for financial support when old.

It is important to note, however, that even among the Taiwanese who expressed "modern" attitudes toward depending on and living with adult children, most still expected to rely on children for support in old age at least a little. This result could indicate the existence of constraints on desired self-reliance, ambivalence toward dependence on children, or inconsistent attitudes toward one's own future in 
contrast to an abstract future situation. A juxtaposition of answers regarding expected reliance on children, saving, and dependence suggests that most Taiwanese favored a system in which they could save but still depend on children for at least some financial support.

\section{Multivariate Analysis of Support Expectations}

Although the bivariate distributions in support expectations are informative, any of the relationships could be accounted for by other factors. For instance, the relationship between education and support expectations could be explained by the relationship between age and education or income and education. The relationship between exposure to mass media and support expectations could be expláined by family income or husband's occupation. I therefore used multivariate analysis to estimate the independent relationship between support expectations and each predictor.

Multivariate estimation is done in several steps, in accordance with a causal assumption that will not be argued at length here. Those who do not accept the assumption, which is that socioeconomic characteristics antecede attitudes related to old-age reliance on children, may still find value in the empirical results. A first step in the multivariate analysis, then, is to enter the socioeconomic characteristics into an equation that does not have any of the attitude variables. The second step is to add the attitude variables to the multivariate equation. This accomplishes two things. First, it estimates the relationship between the attitude variables and support expectations after controlling for socioeconomic characteristics and other attitudes. Second, it estimates the relationship between socioeconomic characteristics and support expectations after controlling for the attitudes.

The support-expectations variable can be analyzed in two parts. A "none/some" part, measuring whether an individual expects to rely at all on children for financial support when old, combines expecting to rely "only a little" and "a great deal." This dichotomy tumed out not to be important numerically at the time of the survey because almost everyone in the Philippines and Taiwan expected to have some reliance on children in old age. It may become more important in the future, however, if parental expectations decline. (See Kobayashi, 1977; Coombs and Sun, 1981.) A second "great/less" part of the support expectations variable distinguishes between expecting to rely on children "a great deal" on the one hand and "only a little" or "not at all" 
on the other. This part distinguished between roughly 40 and 60 percent of the samples.

It is possible that the socioeconomic and attitude characteristics examined here may have different importance for the two ways of distinguishing support expectations. For instance, attitudes may be more important in determining the none/some than the great/less distinction, whereas income and occupation may be more important in determining the great/less distinction.

Before presenting the results of the multivariate analyses, it may be appropriate to give a brief explanation of how to interpret results from logit regression. In the following tables, findings are interpreted in terms of the average (geometric) odds of being in the first rather than the second category of a dichotomous dependent variable. For example, in the Philippines, the odds of having no, versus some, support expectation was on average 1.37 times greater if someone had one more level of education-for instance, grammar school compared with no grammar school (Table 6). The likelihood of expecting not to rely at all was on average 1.51 greater with each increase in income category.

Column 1 in Table 6 contains estimated net effects of various socioeconomic characteristics on none/some support expectations in the Philippines and Taiwan. Findings are close to what one might expect, given the bivariate relationships. Income and respondent's education had significant net effects on none/some support expectations in both countries. Husband's occupation, urban residence, exposure to mass media, and age did not have significant effects in the Philippines but did so in Taiwan. It is particularly noteworthy, given the bivariate significance of husband's occupation, that it did not have a significant effect in the Philippines after income was controlled.

The results of adding the scale of personal efficacy to the equation are shown in Column 2. In the Philippines, the scale had a significant net effect on none/some support expectations but had lit tle effect on the effects of the socioeconomic variables. In Taiwan the personal efficacy scale failed to have a significant net effect on none/some support expectations but it dampened the effect of urban/rural residence.

The effects of further adding a scale of other expected economic help from children (labeled "other economic help") are shown in Column 3 of Table 6 . The net effect of the other economic help scale was quite significant in both countries. In the Philippines the differ- 
TABLE 6. Logistic effects of socioeconomic and attitude factors on none/some support expectations: Philippines (1975) and Taiwan (1976)

(Logits transformed into natural odds)

\begin{tabular}{|c|c|c|c|c|c|c|c|c|}
\hline \multirow[b]{3}{*}{ Variable } & \multicolumn{8}{|c|}{ Support expectations } \\
\hline & \multicolumn{3}{|c|}{ Philippines } & \multicolumn{5}{|c|}{ Taiwan } \\
\hline & (1) & (2) & (3) & (1) & (2) & (3) & (4) & (5) \\
\hline Husband's occupation. & 1.16 & 1.17 & 1.16 & $1.22^{*}$ & $1.26^{*}$ & 1.17 & & 1.16 \\
\hline Residence & 1.01 & 1.02 & 1.19 & $1.47^{*}$ & 1.25 & $1.35^{*}$ & & 1.28 \\
\hline Education & $1.37^{*}$ & $1.35^{*}$ & 1.16 & $2.29^{*}$ & $2.22^{*}$ & $1.67^{*}$ & & $1.56^{\star}$ \\
\hline Family income & $1.51^{*}$ & $1.47^{*}$ & $1.33^{*}$ & $1.53^{*}$ & $1.49^{\circ}$ & $1.43^{*}$ & & $1.37^{*}$ \\
\hline Media exposure & 1.07 & 1.09 & 1.10 & $1.20^{*}$ & $1.19^{*}$ & 1.01 & & 1.09 \\
\hline Age & 1.10 & 1.11 & 1.10 & $1.23^{*}$ & $1.16^{*}$ & $1: 01$ & & 1.10 \\
\hline Personal efficacy & & $1.31 *$ & $1.31^{*}$ & & 1.16 & 1.13 & $1.27^{*}$ & 1.17 \\
\hline Other economic help & & & $8.20^{*}$ & . & & $4.57^{*}$ & $5.21^{*}$ & $3.97^{*}$ \\
\hline Willingness to suppor $t^{a}$ & & & & & & & $1: 19$ & \\
\hline Capable of supporting ${ }^{b}$ & & & & & & & 1.05 & \\
\hline Inconvenient to live with parents ${ }^{c}$ & & & & & & & 1.01 & \\
\hline Savings $d$ & & & & & & & $2.55^{*}$ & $2.25^{*}$ \\
\hline Living arrangements ${ }^{e}$ & & & & & & & $1.50^{*}$ & $1.40^{*}$ \\
\hline
\end{tabular}

- Coefficient is at least twice its standard error.

a. "Do you think young people nowadays are more willing or less willing to support parents in their old age?"

b. "Do you think married young people nowadays are less capable of supporting parents?"

c. "Some people say it is inconvenient to live with parents in this modern industrial society. Others disagree. Do you agree?"

d. "Some people think that a person should save money when young so that he does not have to rely on his children for financial support when he is old. Others disagree. Do you agree?"

e. "To solve the old-age living problem of parents-in-law, which statement do you agree with most strongly? Parents save money when young, and live alone relying on their own savings or pension when they are old. Parents live by themselves, but their children provide financial support. Parents live with their children on a rotational basis; or parents live with one of their children but other children share parents' expenses." 
ence between units of the dichotomous scale increased about eightfold the likelihood of having some expectation of relying on children when old. In Taiwan, the average difference between units of a trichotomous scale more than quadrupled the odds of having some expectation. Adding the other economic help scale also reduced the significant net effect of some of the socioeconomic variables. In the Philippines the effect of education in particular was reduced. In Taiwan the effects of age, exposure to mass media, and husband's occupation were reduced to insignificance. The independent effect of education was reduced but remained significant. Curiously, controlling for other economic help enhanced the effect of residence.

Additional logit regressions are possible with the Taiwanese data because the Taiwan VOC survey asked attitude questions not contained in the cross-national interview schedule (Table 5). A regression of none/some support expectations on the seven attitude variables is shown in Column 4 of Table 6 . Four attitude variables stand out as significant net of the others: personal efficacy, other economic help, savings, and living arrangements. In Column 5 these four attitude variables are added to the socioeconomic variables. The results are similar to those found in Column 3, where personal efficacy and other economic help are added to the socioeconomic variables. Personal efficacy did not have a significant effect, but other economic help, savings, and living arrangements did. The effects of husband's occupation, exposure to mass media, and age were no longer significant. Neither was the estimated effect of urban/rural residence, but it was about the same as in Column 3. These findings support the assumptions that attitudes had an independent effect on none/some support expectations and that the effect of socioeconomic status can be explained in part by attitudes.

The multivariate analysis of the distinction between expecting to rely on children a great deal and less is shown in Table 7. As in the none/some analysis, the net effects of socioeconomic characteristics are shown in Column 1. In both the Philippines and Taiwan the effects of income, occupation, residence, and education were all important. The effects of residence were considerably larger than in the none/ some case. The cross-national similarity in the predictive effect of these standard socioeconomic characteristics is important. On the other hand, the average effects were greater in Taiwan than in the Philippines, especially the effect of education. Mass media and age had 
TABLE 7. Transformed logit coefficients for less/great support expectations on socioeconomic and attitude variables: Philippines (1975) and Taiwan (1976)

\begin{tabular}{|c|c|c|c|c|c|c|c|c|}
\hline \multirow[b]{2}{*}{ Variable } & \multicolumn{3}{|c|}{ Philippines } & \multicolumn{5}{|c|}{ Taiwan } \\
\hline & (1) & (2) & (3) & (1) & (2) & (3) & (4) & (5) \\
\hline Husband's occupation & $1.18^{*}$ & $1.18^{\star}$ & 1.22 & $1.22 *$ & $1.26^{*}$ & $1.17^{*}$ & & $1.15^{*}$ \\
\hline Residence & 1.01 & 1.02 & 1.11 & $1.47^{*}$ & $1.44^{*}$ & $1.53^{*}$ & & $1.38^{*}$ \\
\hline Education & $1.21^{*}$ & $1.20^{*}$ & 1.11 & $2.22 *$ & $2.28^{*}$ & $1.91^{*}$ & & $1.81 *$ \\
\hline Family income & $1.32^{*}$ & $1.31^{*}$ & $1.23^{*}$ & $1.52^{*}$ & $1.51^{*}$ & $1.46^{*}$ & & $1.31^{*}$ \\
\hline Media exposure & 1.04 & 1.05 & 1.05 & $1.21^{\circ}$ & $1.20^{*}$ & $1.13^{*}$ & & $1.17^{*}$ \\
\hline Age & 1.04 & 1.05 & 1.04 & $1.16^{*}$ & $1.23^{*}$ & $1.19^{*}$ & & $1.17^{*}$ \\
\hline Personal efficacy & . & $1.11^{\circ}$ & 1.08 & & 1.10 & 1.06 & $1.28^{*}$ & 1.06 \\
\hline Other economic help & & & $2.94^{*}$ & & & $3.25^{*}$ & $3.86^{*}$ & $2.75^{*}$ \\
\hline Willingness to support & & & & & & & 1.29 & \\
\hline Capable of supporting & & & & & & , & 1.02 & \\
\hline Inconvenient to live with parents & & & & & & & 1.01 & \\
\hline Savings & & & & $\cdot$ & & & $2.03^{*}$ & $1.75^{*}$ \\
\hline Living arrangements & & & & & & & $1.75^{*}$ & $1.68^{*}$ \\
\hline
\end{tabular}

NOTE: See Table 6 for explanations of the attitude variables.

- Coefficient is at least twice its standard error. 
net effects in Taiwan but not in the Philippines. These findings are similar to those in the none/some situation.

Personal efficacy is added to the equation in Column 2. As in the none/some situation, personal efficacy continued to have a net effect in the Philippines but not in Taiwan, once socioeconomic characteristics were controlled for. Additionally, controlling for personal efficacy had little effect on the socioeconomic coefficients. In contrast, adding other economic help (Column 3 ) produced a significant effect on great/less support expectations but less of an effect than on none/ some support expectations. (The standard error for occupation was increased.) In the Philippines a difference of one unit in the dichotomous scale tripled the likelihood of expecting to rely on children a great deal. In Taiwan a difference of one unit in the trichotomous scale enhanced the likelihood by more than three times. Controlling for other economic help also reduced the net effects of the socioeconomic variables. In the Philippines education failed to have a significant net effect after other economic help was controlled for. In Taiwan, however, mass media and age continued to exert a net effect in the case of great/less expectations.

Columns 4 and 5 continue the examination of the effect of attitudes on great/less support expectations in Taiwan. Column 4 shows the net effects of the seven attitude variables before socioeconomic status is controlled for. As in the none/some situation, four of the seven-personal efficacy, other economic help, savings, and living arrangements-had significant effects. They are retained and added to the socioeconomic characteristics in Column 5. Controlling for the four attitudes reduced the net effect of the socioeconomic characteristics, but they remained significant. Except for personal efficacy, the attitude variables stayed significant net of the socioeconomic characteristics. This finding lends substantial support to the notions that part, but not all, of the socioeconomic differential in support expectations was due to factors other than the attitudes measured, and that, likewise, attitudes had a substantial independent effect on support expectations.

\section{Expected old-age reliance on children and fertility preferences}

It has been argued that people without pensions or savings will find greatest old-age insurance in their children (Neher, 1971) and that having more children increases the chance that at least one of them 
will become a filial adult capable of supporting elderly parents (Jones, 1977: Willis, 1981 ; Caldwell, 1982). Testing this hypothesis is complicated by the fact that different family systems have developed different rules for caring for elderly parents. For instance, according to the traditional Chinese norm, sons are responsible for their parents' welfare. According to the traditional Filipino norm, children of both sexes are responsible for parents. The amount of care expected may depend on other types of closeness between parents and children, and other kin or neighbors may be involved. Hence the connection between old-age considerations and fertility preferences could vary considerably between the Philippines and Taiwan. Fertility preferences rather than actual fertility are discussed here because the old-age security hypothesis addresses the demand for children. Since fertility is increasingly being controlled to reflect preferences, understanding the determinants of fertility preferences is an important endeavor.

Table 8 provides preliminary support for my assumptions that support expectations would be positively related to fertility preferences and that this relationship would be stronger in Taiwan than in the Philippines. For instance, there was a gap of .4 in Coombs IN between expecting a great deal of support versus expecting no support in the Philippines, compared with 1.1 in Taiwan. (See Appendix for description of Coombs IN.) The comparable gap in ideal family size was .4 in the Philippines and .9 in Taiwan.

Many things could explain this bivariate relationship. As we have already seen, support expectations were negatively associated with several socioeconomic characteristics known to be associated with fertility preferences (see also United Nations, 1973). If these characteristics were controlled, support expectations might not have a significant relationship with fertility preferences. Demographic factors such as age at marriage, fear of an infant death, actual number of children born, and attitude and knowledge about contraception could also cause a spurious relationship between support expectations and fertility prefe rences.

Controlling for actual fertility and people's knowledge and attitudes about contraception is a conservative stance. It runs the risk of overcontrolling because the causality could easily run the other way-from preferences to actual fertility and attitude about contraception. Examination of the effect of support expectations on Coombs $\mathbb{I N}$ and on ideal family size shows that controlling for current parity and attitude 
TABLE 8. Average preferred fertility by support expectations: Philippines (1975) and Taiwan (1976)

\begin{tabular}{|c|c|c|c|c|}
\hline \multirow[b]{2}{*}{ Country and measure } & \multicolumn{4}{|c|}{ Support expectations (\%) } \\
\hline & Total & None & Little & Great deal \\
\hline \multicolumn{5}{|l|}{ Philippines } \\
\hline Coombs IN $^{8}$ & 4.9 & 4.7 & 4.8 & 5.1 \\
\hline Ideal family size & 3.6 & 3.4 & 3.5 & 3.8 \\
\hline Desired family size ${ }^{c}$ & 4.0 & 3.9 & 3.9 & 4.2 \\
\hline (N) & $(1,530)$ & (153) & (835) & (542) \\
\hline \multicolumn{4}{|l|}{ Taiwan } & ' \\
\hline Coombs IN $\mathrm{N}^{\mathrm{\theta}}$ & 4.7 & 3.9 & 4.4 & 5.0 \\
\hline Ideal family size $e^{b}$ & 3.0 & 2.4 & 2.7 & 3.3 \\
\hline Desired family size ${ }^{c}$ & 3.4 & 2.5 & 3.0 & 3.8 \\
\hline$(\mathrm{N})$ & $(2,085)$ & (265) & (715) & $(1,105)$ \\
\hline
\end{tabular}

a. A scale measuring underlying fertility preferences (see Appendix).

b. The number of children a woman would ideally like to heve if she could start her childbearing over again.

c. The number of children a woman currently has, plus additional wanted children and minus unwanted children. In Taiwan, this was current number of children plus additional wanted children only.

and knowledge about contraception affected the estimated effect of support expectations very little. In contrast, the control had a large effect on the estimated effect on desired family size, which is largely composed of current parity.

In addition, support expectations exist within a matrix of other family orientations. To determine whether support expectations exert an influence on fertility preferences independent from the influence of sex preferences and other economic, social, and emotional values of children, it is necessary to control for these various factors.

Most surveys include few, if any, measures of the value of children. A major strength of the VOC data set is that it contains numerous measures of the value of children besides that of old-age economic support. Measures of other economic values of children included expected labor on the family farm or in the family enterprise, expected wage contributions, and expected contributions toward the cost of a sibling's education (Nag, 1975). Measures of the emotional value of children included children's value as companionship against loneliness and the love and fun that children bring Another, possibly important, measure was the child's value in binding a husband and wife together 
(Hoffman, 1972). Social values of children measured included children's ability to continue a family line and the necessity of having children to fulfill religious or filial responsibilities (Goldsheider, 1971; Lorimer, 1954). The data set contains potentially relevant measures of husband-wife decision making and of the strain felt between mothering and engaging in other social roles (Goldberg, 1975).

Since there were so many possibly relevant measures, I combined individual measures into scales. I then tested the importance of each scale as a possible control for a relationship between support expectations and fertility preferences. If inclusion of the scale made no difference in the estimated effect of support expectations or in the explained variance $\left(R^{2}\right)$, I omitted the scale from the final equation. The subset of possible control variables found to be important for the proper specification of a support-expectations-fertility-preferences relationship in the Philippines and Taiwan consisted of education, residence, husband's occupation, family income, exposure to mass media, age, age at marriage, actual fertility, attitude and knowledge about birth control, sex preferences, ${ }^{5}$ a scale for other economic values of children, and a scale for certain social values of children (see Appendix) ${ }^{6}$

I have presumed that the trichotomous supportexpectations variable is best treated as a set of dummy variables in multiple regression. The dummy contrast between the first two categories is labeled "none/ little." The second contrast is between the second two categories and is labeled "great/little." These contrasts are different from the dichotomies mentioned before, which combined two categories into one to form contrasts between one category and the other two (p. 21). The none/little expectations difference I hypothesized to have little effect on fertility preferences because it distinguishes between people who

5. Measures of sex preference in the Philippines and Taiwan are based on Coombs IS. The Philippine measure emphasizes the strength of either daughter or son preference. The Taiwan measure emphasizes the strength of son preference. (See Appendix.)

6. I left attitude toward birth control in the Taiwan model to satisfy readers who may consider this variable too important to omit despite my empirical finding that it was not important. I omitted income in the case of Taiwan because it is inconsequential for an estimate of an effect of support expectations on fertility preferences once education is controlled for and also because responses on income were missing for 15 percent of the cases. These cases would be lost if 1 included income. 
are fairly "modern" and who tend to desire small families irrespective of the economic value of children (see also Bulatao, 1981). In contrast, the difference between expecting to rely on children a great deal and expecting to rely on them only a little could have a substantial effect on fertility preferences because it probably distinguishes between more or less traditional individuals for whom the economic value of children does affect family-size preferences. (I also investigated the potential importance of several interaction effects. One. was the idea that support expectations could have a greater than average effect among women with nontraditional attitudes toward other family relations, but it proved to be unimportant.)

The net effects on fertility preferences of the two distinctions in support expectations are shown in Table 9. In addition to the three measures of fertility preferences included in Table 8 , results for . whether the respondent wants an additional child are also shown, as are results for the net relationship between support expectations and number of surviving births. (Number of surviving births is a better measure of fertility than parity here since we are.concerned with the old-age security value of children.)

Results for each measure of fertility preferences (Table 9, rows $1-4)$ were consistent in both the Philippines and Taiwan in that there was no net effect of none/little support expectations on fertility preferences, but there was a significant net effect of great/little support expectations. Coëfficients for Coombs IN and for ideal family size were identical for the Philippines sample (.25) and differed by only .02 for the Taiwan sample (.19-.21). The estimates of desired family size are also surprisingly consistent, at roughly one-tenth of a child.

In both the Philippines and Taiwan the coefficients for the desired family-size measure were only half the size of the ones for Coombs IN and for ideal family size. There is a ready explanation for this that illustrates the advantage of using Coombs IN or ideal family size to measure fertility preferences. The scale for desired family size is constructed by adding number of additional wanted children to current parity and subtracting number of unwanted children. Since the measure relies heavily on current parity, current parity overcontrols the relation between the two main variables whereas controlling for parity alters the coefficients for Coombs $\mathrm{IN}$ and for ideal family size hardly at all (figures not shown).

The advantage of considering the effect of support expectations on 
TABLE 9. Multiple regression coefficients for effect of amount of expected reliance on children for financial support when old on selected measures of fertility preferences:

Philippines (1975) and Taiwan (1976)

\begin{tabular}{|c|c|c|c|c|c|c|}
\hline \multirow[b]{3}{*}{ Measure } & \multicolumn{6}{|c|}{ Support expectations ${ }^{a}$} \\
\hline & \multicolumn{3}{|c|}{ Philippines } & \multicolumn{3}{|l|}{ Taiwan } \\
\hline & $\begin{array}{l}\text { Great/ } \\
\text { little }\end{array}$ & $\begin{array}{l}\text { Little/ } \\
\text { none }\end{array}$ & (N) & $\begin{array}{l}\text { Great/ } \\
\text { little }\end{array}$ & $\begin{array}{l}\text { Little/ } \\
\text { none }\end{array}$ & (N) \\
\hline Coombs IN & $.25 t$ & -.03 & $(1,463)$ & $.19 t$ & .01 & $(1,859)$ \\
\hline Ideal family size & $.25 t$ & .02 & $(1,463)$ & $.21 t$ & .03 & $(1,859)$ \\
\hline Desired family size & $.12^{*}$ & .08 & $(1,463)$ & $.11 t$ & .03 & $(1,856)$ \\
\hline $\begin{array}{l}\text { Odds want an } \\
\text { additional child }\end{array}$ & $1.35 t t$ & .74 & $(1,361)$ & $1.54 t t$ & 1.07 & $(1,928)$ \\
\hline Surviving births ${ }^{c}$ & .06 & -.24 & $(1,103)$ & $.16^{*}$ & -.01 & $(1,543)$ \\
\hline
\end{tabular}

NOTE: The regressions control for age, age at marriage, live births, attitude toward contraception, family orientations, and socioeconomic characteristics (see text for de tails).

- Significant at 05 if sample were simple random.

$\uparrow$ Significant at .01 if sample were simple random.

t† Significant at twice its standard error.

a. The measure of support expectations has been transformed into three du mmy variables corresponding to each category (none, little, and a great deal). The "little" dummy has been omitted, and the estimated contrasts are the contrasts between this omitted category and the two included categories.

b. Coefficients for this measure are derived from a logit regression on the odds ratio of wanting more children/not wanting more children. The coefficient refers to the multiplicative effect of the contrasts in their "natural states."

c. The number of children a woman currently has minus any infent or child deaths at the time of the surver.

fertility preferences rather than on actual fertility is also demonstrated. In the Philippines, where fertility has not been widely controlled to reflect people's preferences, support expectations had no effect on actual fertility (Table 9, row 5). In Taiwan, where fertility has been increasingly controlled to reflect people's preferences, support expectations did affect actual fertility.

I had speculated that support expectations might have more effect on fertility preferences in Taiwan than in the Philippines because oldage reliance may have been more concentrated on parents' own children there as opposed to other kin or neighbors. This hypothesis was partially confirmed by the bivariate fertility differentials (Table 8 ), 
indicating that the gap in fertility preferences was much larger in Taiwan than in the Philippines. However, the speculation was not borne out by the multivariate analysis. On the contrary, after I controlled for other factors, the net effect of support expectations on fertility preferences tended to be somewhat greater in the Philippines than in Taiwan for three of the four measures of fertility preferences.

There are two common ways to "control" for other factors when examining a relationship between support expectations and fertility preferences. The first way was performed above. Other factors are entered into a single equation and their average effects controlled for. One may find that controlling for urban/rural residence or for education accounts for part of a bivariate relationship. However, this approach does not take account of the possibility that there is a relationship between support expectations in some categories of the control variable but not in others. For instance, it is possible that a supportexpectations relationship existed among rural residents but not urban ones, or that it existed among people with only a grammar school education or less but not among more highly educated people. To test for this possibility requires a second method of control, commonly used in the perusal of cross-tabulations. Separate regressions must be estimated within each category of the control variable of interest. The advantage of using multiple regression over usual cross-tabular methods is that it is possible to combine the two forms of control by estimating separate regressions using all of the other control variables except the one of special interest, for which the sample is broken into subgroups.

All of the control variables used above could be analyzed in this fashion, but I have selected parity and a few variables from each of three other ty pes: socioeconomic, social-psychological, and family. The list is not intended to be exhaustive. Rather, it is exploratory and based on intuition.

Since the difference between none and little support expectation had no effect on fertility preferences in either the Philippines or Taiwan, the following discussion focuses on the great/little difference in support expectations, which I refer to simply as "support expectation." Estimated coefficients have relatively large standard errors, and differences between coefficients tend not to be statistically significant. The major information to be derived is whether or not an ef fect is significant. Intersociety comparisons can be made on a general level only. 
It would be ideal to use all of the available measures of fertility preferences as a way to test the consistency and reliability of the results. Unfortunately, except for the general overview, it is not possible within the scope of this monograph. I choose to focus on whether an additional child is wanted and on Coombs IN. The estimated coefficients for Coombs IN have standard errors that are smaller than for ideal family size or desired family size. This is an important practical consideration when dealing with relatively small subsamples. Still, there is the possibility that at least some of the insignificant findings may be due to relatively small sample sizes.

Reliability checks on the within-strata estimates disclose occasional inconsistencies between results for Coombs IN and for ideal family size. In most cases these inconsistencies appear explainable by the structural differences in the two measures, which tend to be accentuated among small samples. In most cases, too, Coombs IN appears to yield the more consistent results, probably because it is more sensitive to variation in underlying preferences. The reason for such discrepancies is an area in need of empirical investigation.

\section{Parity Differences}

A component of the hypothesis is that support expectations affect the preferences for higher-order births but not lower-order births because most people want at least a couple of children irrespective of children's perceived economic value. To examine the possible specification of a relationship between support expectations and fertility preferences by parity, it makes most sense to use the variable of whether an additional child is wanted to indicate fertility preferences, since other fertility-preference variables are less related to parity. I therefore used logit regression on the odds ratio of whether an additional child is wanted. The estimated effects are presented in their "natural" state, having been transformed back from their logs.

The findings (Table 10) support the idea that the relationship between support expectations and fertility preferences was specific to higher parities. In neither the Philippines nor Taiwan were support expectations related to whether respondents at parity 0,1 , or 2 wanted an additional child. But in both countries a relationship emerged between support expectations and whether women of parity 3 wanted an additional child-that is, whether they wanted a fourth child. And in the Philippines, among respondents of parity 4 or more, 
TABLE 10. Logistic effect of expecting to rely on children "a great deal" versus "a little" on the odds of whether respondent wants an additional child, by parity: Philippines (1975) and Taiwan (1976)

\begin{tabular}{|c|c|c|c|c|}
\hline \multirow[b]{3}{*}{ Parity } & \multicolumn{4}{|c|}{ Whether an additional child is wanted } \\
\hline & \multicolumn{2}{|c|}{ Philippines } & \multicolumn{2}{|c|}{ Taiwan } \\
\hline & Odds $^{2}$ & $(N)$ & Odds $^{\mathrm{a}}$ & (N) \\
\hline 0 & & (99) & & $(100)$ \\
\hline 1 & .9 & (223) & 1.4 & (233) \\
\hline 2 & .9 & (275) & 1.6 & (346) \\
\hline 3 & $1.9^{*}$ & (258) & $2.9^{*}$ & (522) \\
\hline $4+$ & $2.3^{*}$ & (642) & 1.5 & (761) \\
\hline
\end{tabular}

NOTE: The regressions control for demographic, family, and socioeconomic characteristics (see text).

- Significant at twice its standard error.

a. The coefficients correspond to the odds of wanting an additional child versus not wanting an additional child.

support expectations were related to whether another child was wanted-that is, whether a respondent wanted a fifth or higher-order child.

The country-specific results for parity 4 or more may be explained by the distribution of fertility preferences in the Philippines and Taiwan. In the Philippines 29.0 percent of the sample considered four children to be an ideal number and 16.9 percent considered five or more children to be ideal. But in Taiwan only 2.8 percent considered more than four children to be an ideal number. It is not surprising, then, that support expectations did not have a significant effect in distinguishing this 2.8 percent from the others.

In contrast, the estimated effect of support expectations on whether another child was wanted was substantial among women of parity 3 in Taiwan; the odds of wanting another child were almost 3 to 1 compared with 2 to 1 among the same parity group in the Philippines. This finding is consistent with the idea that there may be a threshold below which desired family size may not drop without radical changes in certain important family orientations and existential circumstances, the old-age economic security value of children being one of these (Freedman et al., 1980). 


\section{Socioeconomic Differences}

Three common indicators of socioeconomic status have been chosen for special consideration: education, residence, and husband's occupation. These variables were found to have a strong dampening effect on the bivariate relationship between support expectations and fertility preferences in both societies (figures not shown). This finding could indicate at least two things: that the average relationship between support expectations and fertility preference was weaker within each subcategory, or that the relationship existed in some categories but not in others. The second interpretation is more likely to be accurate because, as reported in the previous section, people in lower socioeconomic groups tended to have greater support expectations than those in higher socioeconomic groups, and it is the lower socioeconomic groups who also tended to prefer higher fertility (figures not shown).

The estimated effect of great/little support expections on Coombs IN within different socioeconomic subgroups is shown in Table 11. In both countries the size and the statistical significance of the estimated effects declined with increases in status. For instance, in both countries among respondents with less than a primary school education, support expectations had a significant net effect of .40 on Coombs IN, but among respondents with a junior high school education or more the effect was insignificant, at most .05. The coefficients for other variables were not as similar but followed that same general pattern. For instance, support expectations had a significant effect of .23 among rural residents but an insignificant effect of .18 or .08 among urban residents.

There were differences between countries, of course. For husband's occupation, for instance, the effect of support expectations on Coombs IN occurred among respondents of higher socioeconomic status in Taiwan than in the Philippines. In Taiwan only respondents whose husbands had white-collar occupations showed no significant relationship between support expectations and fertility preferences whereas in the Philippines only the farming and fishing respondents did show a significant relationship. This finding could have several explanations, including the countries' different traditional family structures or lengths of exposure to modernizing forces. Another possibility is that the smaller sample sizes, coupled with the number 
TABLE 11. Multiple regression contrast of great/little support expectations on Coombs IN by selected socioeconomic characteristics: Philippines (1975) and Taiwan (1976)

\begin{tabular}{|c|c|c|c|c|}
\hline \multirow[b]{2}{*}{ Characteristic } & \multicolumn{2}{|l|}{ Philippines } & \multicolumn{2}{|l|}{ Taiwan } \\
\hline & Great/little & (N) & Great/little & (N) \\
\hline \multicolumn{5}{|l|}{ Education } \\
\hline Junior hight & .04 & $(570)$ & .05 & $(338)$ \\
\hline Grammar & $.31^{*}$ & $(487)$ & $.16 t$ & $(1,109)$ \\
\hline$<$ grammar & $.40 \dagger$ & (425) & $.43 t$ & (407) \\
\hline \multicolumn{5}{|l|}{ Residence } \\
\hline Urban & .18 & $(303)$ & .08 & (346) \\
\hline Urban barangay & .18 & $(162)$ & & \\
\hline Rural barangay/mix & $.56^{*}$ & $(140)$ & $.17^{*}$ & $(817)$ \\
\hline Rural & $.23 t$ & (871) & $.23 \dagger$ & (691) \\
\hline \multicolumn{5}{|l|}{ Husband's occupation ${ }^{a}$} \\
\hline Upper white-collar & .55 & (73) & .07 & (467) \\
\hline Mid/low white-collar & .18 & (318) & $.24 t$ & $(726)$ \\
\hline Upper blue-collar & na & na & $.27 t$ & (469) \\
\hline Lower blue-collar & .06 & $(414)$ & $.26^{*}$ & $(282)$ \\
\hline Farming/fishing & $.33 t$ & $(556)$ & $.23^{*}$ & (388) \\
\hline
\end{tabular}

NOTE: The regressions control for age, age at marriage, knowledge and attitude about contraception, parity, family orientations, and socioeconomic charecteristics other than the one being stratified.

no-not applicable.

- Significant at .05 if sample were simple random sample.

+ Significant at .01 if sample were simple random sample.

of control variables employed in the multivariate analysis, in some cases obfuscated the existence of a true relationship (De Vos, 1983).

\section{Social-Psychological Differences}

The possibility of an individual, social-psychological effect on the relationship between support expectations and fertility preferences is also of interest. In the previous section I reported that a scale of personal efficacy was related to support expectations before socioeconomic variables were controlled for (Tables 7 and 8 ). Instead of estimating the great/little support-expectations effect within categories of the personal efficacy scale, however, it is more advantageous to control for two of the scale's constituent variables because the results are more easily interpretable. I also selected another social- 
psychological variable for special analysis, what the respondent considered most important to her. Of particular interest to me was whether emotional matters, financial security, or family continuity was considered most important. I regarded the variables of personal efficacy and the most important thing as good social-psychological controls because they were not explicitly related to, and were theoretically independent of, the value of children.

I hypothesized that individuals who view planning ahead as useful, who believe they influence things that happen to them, or who regard financial security as the most important thing in life will tend to be influenced by support expectations in their fertility preferences because it is they who will tend to see old-age insurance in having children. On the other hand, for people who do not believe in planning, believe they have little influence over their lives, or consider emotional attachments to be most important, old-age considerations will probably have little effect on their desire for children.

The hypothesis is complicated by the fact that people with strong feelings of efficacy could have confidence in providing for themselves in old age and therefore tend to expect to rely less on children (Table 5). However, it is also among this group, I conjecture, that the intensity of support expectations and fertility preferences would be strongest. Hence, there could be a stronger relationship between the two characteristics than among people with lower feelings of efficacy.

Regression analysis failed to bear out this hypothesis (Table 12). Perhaps because of the complication mentioned above, no consistent pattern emerged in the way social-psychological characteristics specified the support-expectations effect. For instance, a significant effect of support expectations was'observed among the group who agreed strongly that "it is not wise to plan too far ahead" in the Philippines, but no such effect surfaced for the same group in Taiwan. A similar inconsistency can be observed for the personal efficacy variable. I observed yet another ambiguity in the Taiwan data when examining the relationship between support expectations and fertility preferences within categories of a scale of social-psychological modernity that could have "smoothed" out idiosyncratic answers to several socialpsychological questions. In contrast, results using the Philippine scale were consistent with the hypothesis.

The only finding that supports the hypothesis is that there was a significant support-expectations effect among people who considered 
TABLE 12. Multiple regression contrast of great/little support expectations on Coombs IN by selected socialpsychological orientations: Philippines (1975) and Taiwan (1976)

\begin{tabular}{|c|c|c|c|c|}
\hline \multirow[b]{2}{*}{ Orientation } & \multicolumn{2}{|c|}{ Philippines } & \multicolumn{2}{|l|}{ Taiwan } \\
\hline & $\begin{array}{l}\text { Great/ } \\
\text { little }\end{array}$ & (N) & $\begin{array}{l}\text { Great/ } \\
\text { little }\end{array}$ & (N) \\
\hline \multicolumn{5}{|c|}{$\begin{array}{l}\text { It is not wise to plan too far } \\
\text { ahead }\end{array}$} \\
\hline Disagree & .12 & (450) & $.21 t$ & $(576)$ \\
\hline Àgree slightly & .14 & (513) & $.27 t$ & (649) \\
\hline Agree strongly & $.47 \dagger$ & (543) & .09 & (629) \\
\hline \multicolumn{5}{|c|}{$\begin{array}{l}\text { You have little influence over } \\
\text { the things that happen to you }\end{array}$} \\
\hline Disagree & .20 & (470) & .16 & (281) \\
\hline Agree slightly & .12 & (526) & $.25 t$ & (882) \\
\hline Agree strongly & $.42 \dagger$ & (510) & .16 & (281) \\
\hline \multicolumn{5}{|c|}{$\begin{array}{l}\text { Emotional considerations, } \\
\text { financial security, or continuation } \\
\text { of the family name is the most } \\
\text { important thing }\end{array}$} \\
\hline Emotions & .18 & (777) & $.23 t$ & $(817)$ \\
\hline Financial security & $.30 t$ & (597) & $.28 \uparrow$ & $(400)$ \\
\hline Family continuity & $.59^{*}$ & (108) & .09 & (637) \\
\hline
\end{tabular}

NOTE: The regressions control for age, age at marriage, knowledge and attitude about contraception, parity, family orientations, and socioeconomic characteristics.

- Significant at 05 if sample were simple random sample.

† Significant at .01 if sample were simple random sample.

financial security to be the most important thing. Yet among people who considered family continuity most important, the supportexpectation effect was significant in the Philippines but not in Taiwan. Obversely, there was such an effect among people who considered emotional matters most important in Taiwan but not in the Philippines.

One cannot overemphasize the difficulty in devising socialpsychological survey measures that are truly comparable across cultures. It is possible that the VOC questions had different interpretations for respondents in the Philippines and Taiwan. It is also possible that the measures used are comparable between societies but do not 
illuminate the determinants of a support-expectations-fertilitypreferences relationship.

\section{Differences in Family Orientation}

Support expectations exist within a matrix of family orientations about children. The question naturally arises, therefore, whether there are other orientations that could help specify the support-expectations -fertility-preferences relationship. Three variables are selected here for perusal out of the many possible variables contained in the survey. They are religion ("How important is your religion as a reason to have children?"), strain ("How much worry or strain do children cause?"), and sex preference (that is, preference for children of a particular sex). ${ }^{7}$

The religion variable captures a dimension of family orien tation thought to change radically with development (Barnes, 1952) and of traditional importance to the sociologist. Responsibility in the care of elderly parents is furthermore a moral obligation taught by most religions. Hence I hypothesized that a support-expectations effect would more likely occur among individuals who considered religion an important reason to have children than among other individuals.

Results of the empirical analysis (Table 13) did not entirely support this conjecture, however. As expected, in the Philippines there was a support-expectations effect among people who considered religion to be important but not among people who did not consider it important. In Taiwan there was a support-expectations effect among people who considered religion to be very important, but there was also such an effect among people who considered religion unimportant.

Central to the old-age security hypothesis is the notion that the support-expectations effect exists where there is little perceived cost to having many children, where a number/quality tradeoff does not exist. If couples perceived such a tradeoff, they might consider it wiser to have only a few children who would be able to support the parents handsomely in their old age rather than to have many children with little ability to support the parents (Caldwell, 1982; De Vos, 1983).

7. The support-expectations-Coombs-IN relationship was also examined within two ty pes of household, nuclear and extended. In both countries the relationship was significant within both household types. In neither country was there any indication of a difference in the size of the estimated relationship according to type of household. 
TABLE 13. Multiple regression contrast of great/little support expectations on Coombs IN by selected family orientations: Philippines (1975) and Taiwan (1976)

\begin{tabular}{lllll}
\hline & - & Philippines & & Taiwan \\
\cline { 3 - 5 } & Great/ & Great/ & \\
Orientation & little & (N) & little & (N) \\
\hline
\end{tabular}

How important is your religion as a reason to have children?

Not important

Somewhat important

Very important

How much worry or strain do children cause?

Very much

Some

Little/none

Sex preference ${ }^{a}$

Neutral

Moderate

Strong
.09

$.50 t$

$.26 t$

.10

$.25 t$

$.39 t$

.06

$.25 t$

$.43 t$
(322)

(467)

(693)

$.20^{*}$

.14

$.20 t$

(280)

(747)

(474)

$.28 t$

.03

.31 *

(381)

.15

(700)

$.24 t$

(401)
(693)

(691)

NOTE: The regressions control for age, age at marriage, attitude and knowledge about contraception, parity, various family orientations, and socioeconomic characteristics (see text for details).

- Significant at .05 if sample were simple random sample.

+ Significant at .01 if sample were simple random sample

a. Based on Coombs IS preference scale. In the Philippines, th is orientation refers to strength of either girl or boy preference. In Taiwan, it refers only to strength of son preference.

(See Appendix.)

This notion motivated the selection of the strain variable. I conjectured that there would be a support-expectations effect among respondents who félt little or no strain from having children. In contrast, there would be no such effect on fertility preferences among people who felt a lot of strain from having children.

The empirical test, shown in Table 13, did not provide clear support for the strain conjecture. In the Philippines, it is true, there was a support-expectations effect among people who perceived little or only some strain from having children, and the estimated effect was greatest among those who perceived little or no strain. Yet the Taiwan findings went against expectations. Most respondents considered 
children to cause a great deal of worry or strain, but there was a substantial support-expectations effect among those individuals. Again, the strain question appears to have meant different things to respondents in the Philippines and Taiwan. In the Philippines the proportion perceiving a great deal of strain appears more in line with what was expected-about one-six th of the sample. Thus no positive statement can be made concerning the impact of a number/quality tradeoff on a support-expectations effect.

I also wanted to test the idea that people without a preference for the sex of their offspring probably do not connect old-age security considerations with fertility preferences whereas people with a strong sex preference probably do make such a connection. This argument appears more compelling for Taiwan than for the Philippines since, in Taiwan, people tend to depend on sons only whereas in the Philippines they tend to depend on children of both sexes. In fact, I measured the strength of sex preference differently in the Philippines than in Taiwan. A "strong" sex preference in the Philippines referred to a strong preference for either boys or girls, but it was specific to a strong preference for boys in Taiwan (see Appendix).

As with the other two family variables, the expected effects, shown in Table 13, were found in the Philippines but not in Taiwan. In the Philippines, the strongest support-expectations effect was found among individuals with a strong sex preference, but there was no significant effect among people with a neutral sex preference. In Taiwan, in contrast, there was no significant support-expectations effect among people with a neutral sex preference or a strong boy preference. A closer examination of this.latter finding disclosed a high correlation between having a strong boy preference and expecting to rely on children a great deal. There may have been insufficient possibility for covariation among this group for there to be a significant effect (figures not shown).

\section{Sex preference and expected financial support from children}

People in most societies exhibit a preference for children of one sex over another, for still poorly understood reasons (Williamson, 1976). Where there is a preference for one sex by an overwhelming majority of a society, it is often hypothesized that the society has ascribed different, and unequal, functional values to daughters and sons. For instance, in societies with families organized patrilineally, such as 
among the Chinese, sons only are permitted to continue the family line, and they are expected to care for their elderly parents. Daughters, on the other hand, marry into their husbands' families (Goode, 1970; Baker, 1979). Yet daughters may have more emotional value than sons, at least to fathers. Whereas fathers may relate to their sons along formal, socially expected lines, they may feel freer to establish warm, spontaneous relationships with their daughters (Baker, 1979). The economic and family-continuity factors seem to dominate sex preferences, however, because people in patrilineal societies prefer sons (Freedman and Coombs, 1974; Williamson, 1976; Coombs and Sun, 1981).

The situation in the Philippines has been quite different from that among the Chinese, for the traditional family has been bilineal, not patrilineal. Daughters as well as sons stay attached to parents' kin groups after marriage and are expected to care for elderly parents. There is no structural or religious need to produce an heir in the Philippines the way there has been in Chinese society (Vreeland et al., 1979; Yu and Liu, 1980). According to a functional perspective, then, it may not be surprising that Filipinas in the VOC study were more or less evenly divided between preferring daughters and preferring sons, and that about a quarter preferred a balance of daughters and sons. The determinants of variation in sex preference in the Philippines, in contrast to Taiwan, appeared less socially determined and were, perhaps, more psychologically determined.

\section{Differences Between the Two Societies}

The marked contrast between the Philippines and Taiwan in support expectations and sex preferences is shown in Tables 14 and 15. In the Philippines only 14 percent of the sample expressed different support expectations for sons and daughters (Table 14). In Taiwan more than two-thirds of the sample expressed greater support expectations for sons than for daughters. For instance, 50 percent of the sample reported expecting a great deal of support from sons but not from daughters. Less than 1 percent of the sample reported expecting a great deal of support from daughters but not from sons. There was as much daughter preference as son preference in the Philippines (39 versus 36 percent of the sample), whereas only 8 percent of the Taiwan sample did not prefer sons (Table 15).

There is also strong empirical support for the notion that old-age 
TABLE 14. Percentage of VOC respondents who expected to rely on sons and daughters for financial support when old: Philippines (1975) and Taiwan (1976)

\begin{tabular}{|c|c|c|c|c|}
\hline \multirow[b]{2}{*}{ Expectation } & \multicolumn{2}{|c|}{ Philippines } & \multicolumn{2}{|c|}{ Taiwan } \\
\hline & $\%$ & (N) & $\%$ & (N) \\
\hline No support from either & 10 & $(159)$ & 13 & (277) \\
\hline $\begin{array}{l}\text { Little support from son, none from } \\
\text { daughter }\end{array}$ & 2 & (29) & 19 & (428) \\
\hline $\begin{array}{l}\text { Little support from daughter, none } \\
\text { from son }\end{array}$ & 2 & (38) & * & (3) \\
\hline Little support from both & 50 & $(810)$ & 15 & $(321)$ \\
\hline $\begin{array}{l}\text { Great support from son, none from } \\
\text { daughter }\end{array}$ & 1 & $(14)$ & 28 & $(620)$ \\
\hline $\begin{array}{l}\text { Great support from daughter, none } \\
\text { from son }\end{array}$ & 1 & (14) & * & (1) \\
\hline $\begin{array}{l}\text { Great support from son, little from } \\
\text { daughter }\end{array}$ & 5 & (75) & 22 & (498) \\
\hline $\begin{array}{l}\text { Great support from daughter, little } \\
\text { from son }\end{array}$ & 3 & $\cdot(50)$ & $*$ & (5) \\
\hline Great support from both & 26 & (424) & 3 & (64) \\
\hline
\end{tabular}

- Less than 1.

support considerations were strongly tied to sex preferences in Taiwan but not in the Philippines. The cross-tabulations of support expectations from sons and sex preference are shown in Table 16. (It is worth remembering that in the Philippines support expectations from daughters were almost identical with support expectations from sons whereas in Taiwan it was possible to collapse no preference, slight daughter preference, and strong daughter preference into one category because so few respondents expressed anything but son preference.) In the Philippines respondents expressed the same distribution of support expectations irrespective of their sex preferences. In Taiwan respondents with a strong son preference were much more likely than others to expect a great deal of support from sons.

This leads to the proposition that expected reliance on sons for financial support in old age is related to, and may help cause, son preference under certain conditions but not under others. The nature of the lineage system, whether it is patrilineal or bilineal, appears to 
TABLE 15. Percentage distribution of individual sex preference (Coombs IS): Philippines (1975) and Taiwan (1976)

\begin{tabular}{lrrrrr}
\hline & \multicolumn{2}{c}{ Philippines } & & \multicolumn{2}{c}{ Taiwan } \\
\cline { 2 - 3 } \cline { 5 - 6 } Coombs IS & $\%$ & (N) & & \multicolumn{1}{c}{ (N) } \\
\hline 1.' (Daughter) & 2 & $(36)$ & & 0 & $(2)$ \\
2. & 11 & $(177)$ & & 1 & $(11)$ \\
3. & 26 & $(418)$ & & 1 & $(26)$ \\
4. (Neutral) & 26 & $(418)$ & & 6 & $(126)$ \\
5. & 22 & $(355)$ & & 59 & $(1,193)$ \\
6. & 12 & $(201)$ & & 32 & $(641)$ \\
7. (Son) & 2 & $(7)$ & & 1 & $(29)$ \\
\hline
\end{tabular}

NOTE: Coombs IS is an ordinal scale ranging from strong daughter preference (1) to strong son preference (7). (See Appendix for details.)

be an important factor. But what about possible change in the relationship between expected reliance on sons and son preference within a traditionally patrilineal society itself? The question is worth asking because son preference is part of a central patrilineal pivot around which the traditional Chinese family operates. Examining the relationship could provide valuable insight into the "modernization" of the Chinese family.

\section{Association Between Sex Preference and Support Expectations in} Taiwan

Two avenues seem possible for a looser connection between son preference and expected reliance on sons over time in Taiwan. One is that one or both of the elements in the traditional relationship attenuates so that covariation becomes impossible. That is, either support expectations from sons or son preference disappears. A second way is that the traditional orientations persist but they become less and less associated with each other. This would seem particularly possible if the traditional association were not causal.

The cross-sectional VOC data provide a clue as to whether there is a diminishing relationship between expected reliance on sons and son preference in Taiwan if one assumes, tentatively at least, that socioeconomic differentials express differences in modernity level and indicate directions of change. There is considerable support for this assumption. In general, upper strata appear to adopt many new atti- 
TABLE 16. Sex preference by amount of expected reliance on sons when old: Philippines (1975) and Taiwan (1976)

\begin{tabular}{lccccc}
\hline & \multicolumn{5}{c}{ \% distribution of expected reliance } \\
\cline { 2 - 6 } Country and sex preference & None & Little & Great & Total & (N) \\
\hline Philippines & & & & & \\
$\quad$ Strong daughter (IS 1,2) & 12 & 12 & 15 & 13 & $(210)$ \\
Slight daughter (IS 3) & 27 & 25 & 27 & 26 & $(415)$ \\
Neutral (IS 4) & 26 & 26 & 24 & 25 & $(410)$ \\
Slight son (IS 5) & 26 & 23 & 18 & 22 & $(352)$ \\
Strong son (IS 6,7) & 9 & 14 & 16 & 14 & $(226)$ \\
Total & 100 & 100 & 100 & 100 & \\
& $(211)$ & $(899)$ & $(518)$ & $(1,613)$ & \\
Taiwan (son preference) & & & & & \\
$\quad$ None (IS 1-4) & 21 & 10 & 4 & 8 & $(162)$ \\
$\quad$ Moderate (IS 5) & 62 & 67 & 53 & 59 & $(1,192)$ \\
$\quad$ Strong (IS 6,7) & 17 & 23 & 43 & 33 & $(667)$ \\
Total & 100 & 100 & 100 & 100 & \\
(23) & $(239)$ & $(678)$ & $(1,104)$ & $(2,021)$ & \\
\hline
\end{tabular}

tudes toward the family before lower strata do (Sun, 1968; Coombs and Sun, 1981). For instance, in 197091 percent of a national sample of childbearing-age women with no formal education in Taiwan reported that they expected to be supported by their sons in old age, compared with 78 percent of the sample with a primary school education (Coombs and Sun, 1981:1241). By 1973 the differential had changed to 75 and 51 percent, respectively. Thus, although the proportion of each educational group who expected old-age support from sons had shifted downward during the three years, a higher proportion of the group with no education still expected support.

The Value of Children survey contained measures of various factors that must be controlled in order to determine an independent relationship between expected reliance on sons and son preference. These include attitudes toward such characteristics as family continuity (importance of continuing the family name, importance of having a son, other expected economic help from sons, religiosity, and filiality), which are generally associated with the traditional, patrilineal Chinese family; the emotional value of children (measured by the importance attached to statements "because children are fun," "so as not to be 
lonely," and "to have someone to love," as reasons to have children), 8 and socioeconomic characteristics (age, education, urban/rural residence, husband's occupation, and family income) ${ }^{9}$

One may conceptualize both expected reliance and son preference as comprising two important distinctions each. For expected reliance on sons, the distinctions are whether someone expects no support or a little support from sons (none/little) and whether someone expects a great deal or little support from sons (great/little). Earlier in this paper I reported that the none/little contrast had no independent effect on fertility preferences whereas the great/little contrast had a considerable effect. For son preference there is an important distinction between whether someone has no preference or a moderate preference for sons (none/moderate) and whether someone has a strong or only moderate preference for sons (strong/moderate). A minority of the sample expected no support in old age from sons, and a minority did not prefer sons; yet it is important to distinguish these groups from the others. If they were not distinguished, the groups having no preference would be overwhelmed statistically by the numbers in the other groups.

The relationship between expected reliance on sons and son preference is schematized as fourfold (Figure 1). Since people with little or no expectations are assumed to have a moderate preference or no preference for sons, and people with great or some expectations from sons are assumed to have a strong or moderate preference for sons, most people are expected to be represented in cells A or D of Figure 1. To calculate this relationship, I treated the two son-preference dichotomies (none/moderate and strong/moderate) separately in two conditional logit multiple regressions. Odds are conditional in that people must be in one of the two categories. Categories of expected reliance are treated as $0-1$ dummy-variable contrasts. (In Table 17, for instance, figures in the first column correspond to the conditional odds of having no son preference versus a moderate son preference. People

8. 1 added the measures of the emotional value of children because daughters could have more emotional value than sons. In fact, I found that the emotional value of children did have a negative effect on son preference, in particular on the dichotomy between no preference and moderate preference (De Vos, 1982). At present, economic factors disguise the effect on the bivariate level.

9. Ideally, fear of infant or child mortality should also be controlled since it could influence the preference for a minimum of two sons rather than one son. Unfortunately, I do not have a measure of this. 
FIGURE 1. Hypothetical relationship between expected reliance and son preference

Son preference

\begin{tabular}{lcc}
\cline { 2 - 3 } Expected reliance & None/moderate & Strong/moderate \\
\hline None/little & $A^{*}$ & B \\
Great/little & $C$ & $D^{*}$ \\
\hline
\end{tabular}

-A relationship between expected reliance and son preference is hypothesized to exist most strongly in cells $A$ and $D$.

having a strong son preference are excluded from the computation. Figures in the first row correspond to the effect of expecting to rely on sons not at all versus only a little. The effects are considered in multiplicative terms, and identity is 1.00 .) Of the many possible controls, the following were found to be important in the final analysis: the importance of continuing the family name, the importance of having a son, religiosity and filiality, the emotional value of children, and urban/rural residence. That expectations of other economic help may not be important in the multivariate context could be due to the concept's measurement (De Vos, 1982).

For the entire VOC sample the empirical relation between son preference and expected reliance on sons, controlled for various factors, is shown in Table 17. My hypothesis was that the none to strong diagonal would be important (cells $A$ and $D$ ). In fact, there was a relationship among three of the four possible combinations of son preference and expected reliance under consideration-all but the combination of strong/moderate and none/little (cell B). A significant difference emerged in the proportions of individuals with no son preference between those who expected to rely on sons only a little and those who expected to rely on them not at all, but there was little difference in the proportions with a strong son preference between those groups (see Table 15).

\section{Socioeconomic Differences}

Differences among socioeconomic groups in the nature of the relationship between expected reliance on sons and son preference could indicate how the relationship might evolve during the modernization 
TABLE 17. Estimated net relationship between expected reliance and son preference: Taiwan (1976)

(Using conditional logit odds)

\begin{tabular}{|c|c|c|c|c|}
\hline \multirow{3}{*}{$\frac{\text { Expected reliance }^{\text {b }}}{\text { None/little }}$} & \multicolumn{4}{|c|}{ Son preference ${ }^{a}$} \\
\hline & \multicolumn{2}{|c|}{$\begin{array}{l}\text { None/moderate } \\
\text { logit factor }\end{array}$} & \multicolumn{2}{|c|}{$\begin{array}{l}\text { Strong/moderate } \\
\text { logit factor }\end{array}$} \\
\hline & $1.34^{*}$ & (A) & .97 & (B) \\
\hline Great/little & $.74^{*}$ & (C) & $1.38^{*}$ & (D) \\
\hline Total & $(1312)$ & & $(1816)$ & \\
\hline
\end{tabular}

NOTE: The odds are conditional on being in either of the two (of threel possible sonpreference categories. The regressions control for importance of continuing the family name, the importance of having a son in the family (general), scale of religiosity and filiality, the emotional value of children, and urban/rural residence.

- Significant at twice its standard error.

a. From the Coombs IS scale; none $=$ IS $1-4 ;$ moderate $=$ IS 5 ; strong $=$ IS 6-7.

b. "(If you had sons) would you expect your son(s) to support you financially when old a great deal, only a little, or not at all?"

of a society. The hypothesis, depicted in Figure 2, is as follows: At an early stage of modernization the relationship is primarily between traditional (great) expectations and traditional (strong) son preference (cell D). Since most people have traditional values, other aspects of the relationship (cells $\mathrm{A}-\mathrm{C}$ ) are unimportant. As modernization progresses (stage 2) and more people begin to have lower expectations and neutral sex preferences, the expected-reliance-son-preference relationship involves all four combinations (cells A-D). At an even later period of modernization (stage 3), few people expect to rely on children a great deal or have a strong son preference. Thus, contrary to the situation in stage 1 , the relationship is primarily between nontraditional expectations (none) and nontraditional (neutral) sex preferences (cell A). For the whole VOC sample the relationship is characteristic of stage 2 (Table 17).

I was interested in learning whether different socioeconomic strata exhibited the same type of relationship or different types. Relationships between expected reliance and son preference within different educational, residential, and income strata are shown in Table 18. (Examining the relationship within several socioeconomic groupings provides a modest consistency check on the findings.) In the lowest strata (rural, illiterate, income of less than NT\$4,000 per month), 
FIGURE 2. Hypothetical relationship between expected reliance and son preference at different stages in the modernization process

Son preference

Expected reliance

and modernization stage

None/moderate

Strong/moderate

Stage 1

$\begin{array}{lll}\text { None/little } & 0 \text { (A) } & 0 \text { (B) } \\ \text { Great/little } & 0 \text { (C) } & + \text { (D) }\end{array}$

Stage 2

None/little

$?$ (A)

$?$ (B)

Great/little

$?$ (C)

$?$ (D)

Stage 3

None/little

$+\quad 0$

Great/little

0

0

+- Relationship.

$0-$ No relationship.

?-Possible relationship.

there were too few cases for a relationship between none/lit tle expected reliance and son preference (cells $A$ and $B$ ). However, there were significant relationships between great/little expected reliance and both son-preference dichotomies. They would seem closer to a stage 2 relationship than to a stage 1 relationship. Findings for the next strata (urban, primary-school education, income of NT $\$ 4,000-$ 9,999 per month) were even more consistent with the hypothesized stage 2 relationship in that the none/none expected-reliance and the great/strong son-preference combinations were important whereas the none/strong combinations were not. Findings for the higher educational and income strata were less reliable than those for the other strata because of smaller sample sizes; but they seemed to reflect the expected-reliance-son-preference relationship of the overall sample rather than the relationship hypothesized for stage 3 of modernization.

In summary, I had speculated that there were two possible ways in which the traditional relationship between expected reliance on sons 
TABLE 18. Estimated net relationship between expected reliance and son preference within selected socioeconomic strata: Taiwan (1976)

(Using conditional logit odds)

\begin{tabular}{lcc}
\hline $\begin{array}{l}\text { Socioeconomic stratum and } \\
\text { expected reliance }\end{array}$ & \multicolumn{2}{l}{ Son preference $^{\mathrm{b}}$} \\
\cline { 3 - 3 } $\begin{array}{l}\text { None/moderate } \\
\text { Notample }\end{array}$ & Strong/moderate \\
$\begin{array}{l}\text { None/little } \\
\text { Great/little }\end{array}$ & $1.34^{*}$ & .97 \\
Rural $^{\mathrm{d}}$ & $.74^{*}$ & $1.38^{*}$ \\
None/little $^{\mathrm{c}}$ & & \\
Great/little $^{\mathrm{d}}$ & & \\
(N) & $.56^{*}$ & $1.41^{*}$ \\
Urban & $(411)$ & $(714)$ \\
None/little & & \\
Great/little & & 1.00 \\
(N) & .82 & $1.43^{*}$ \\
& $(901)$ & $(1.102)$
\end{tabular}

Illiterate

None/little $e^{c}$

Great/little ${ }^{d}$

$.42^{*}$

(N)

(235)

Primary education

None/little ${ }^{c}$

$1.45 \uparrow$

1.03

Great/little

(N)

(782)

$(1,090)$

Junior hight education

None/little ${ }^{c}$

1.21

.95

Great/little ${ }^{d}$

(N)

(278)

Income $<4,000^{\dagger}$

None/little ${ }^{c}$

Great/little ${ }^{d}$

(N)

(203)

Income 4,000-9,999

None/little ${ }^{c}$

Great/little

$1.72^{*}$

.80

.92

$1.30^{*}$

(N)

(691) 
TABLE 18. (continued)

\begin{tabular}{lcc}
\hline Socioeconomic stratum and & \multicolumn{2}{l}{ Son preference } \\
\cline { 2 - 3 } expected reliance $^{\mathrm{b}}$ & None/moderate & Strong/moderate \\
\hline Income $10,000+^{\mathrm{f}}$ & & \\
None/littlec & .96 & .93 \\
Great/little & .56 & 1.20 \\
(N) & $(251)$ & $(276)$ \\
\hline
\end{tabular}

NOTE: The odds are conditional on the respondent being in either one or the other category lout of three possible). Cells are blank if the total number of respondents expecting to rely not at all is less than 35 . The regressions control for importance of continuing the family name, importance of having a son in the family (general), religiosity and filiality. the emotional value of children, and rural/urben residence.

- Significant Bt twice its standard error.

† Significant at 1.86 times its standard error.

a. "(If you had sons) would you expect to rely on your son(s) a great deal or only a little for financial support when old?"

b. From Coombs ideal-sex scale. "None" = IS 1-4; "moderate" = is 5; "strong" = IS 6-7.

c. Cells $A$ and $B$.

d. Cells $C$ and $D$.

e. Rural respondents were those who had lived their entire lives in a rural area; urban respondents were all others.

f. Family income calculated in NT\$ per month.

for financial support in old age and son preference might weaken. One was by the attenuation of one or both of the traditional values. The other was by greater independence between the two values despite their persistence. The findings regarding the possibility of the second way were negative. Where there were enough cases for the possibility of significant covariation between expected reliance and son preference, significant covariation appeared. The implication of these crosssectional findings is that a relationship between expected reliance on sons and son preference might disappear only when expected reliance or son preference disappears.

\section{The Effect of a Government Pension}

One policy implication of the relationship between expected reliance on sons for old-age support and son preference is that a government pension might weaken son preference if it weakened expected reliance. The Taiwan VOC survey asked the following question: "If the government established a good program so that you would be paid a pension 
when you grew old ... [how] ... important [would it be] to have a son in the family?" Answers to the question were used to evaluate the possible effect of a pension on the relationship between expected reliance and son preference. However, I approached the exercise cautiously. A hypothetical question is difficult for people to answer, especially if it describes a situation about which they might not have previously thought. People may have varying degrees of trust in a government pension program and may estimate their reactions accordingly. They may differ considerably in their interpretations of a "good" pension program. Whereas some may in terpret "good" to mean "realistically possible given present government resources," others may consider it to mean "in the best of all possible worlds." Moreover, only people who expected at least some support from their sons were asked this question because the introduction of a pension program would presumably have no effect on the son preference of respondents who said they expected no support from sons.

The effect of controlling for the resulting pension variable on the relationship between great/little expected reliance and son preference is shown in Table 19. Son preference, as before, was treated as two dichotomies. Columns 1 and 3 of Table 19 show the estimated effects of expected reliance without controlling for pension. (These effects may differ slightly from the previous results because I did not include respondents who did not expect to rely on sons at all.) Columns 2 and 4 show the coefficients with pension controlled. The figures showed no effect of controlling for pension on the coefficient for either the son-preference dichotomy for the total sample (row 1) or for the none/moderate cells among different residential, educational, or income strata.

Table 19 does reveal a slight effect of controlling for pension on the relationship between great/little expected reliance and strong/moderate son preference among the lower strata. If one compares the figures for rural respondents in columns 4 and 5 , for instance, the great/little expected reliance coefficient is altered from a significant 1.32 to an insignificant 1.18 when pension is controlled. Although less dramatic, there is a similarly significant difference among the illiterate and lowincome groups with pension controlled.

A statistical test showed that the coefficient controlled for pension cannot be considered significantly different from the coefficient not controlled for pension, but this finding was expected given the large 
TABLE 19. Effect of a hypothetical government pension on the relationship between expected reliance and son preference within selected socioeconomic strata: Taiwan (1976)

(Using conditional logit)

\begin{tabular}{|c|c|c|c|c|c|c|}
\hline \multirow[b]{3}{*}{ Socioeconomic stratum } & \multicolumn{6}{|c|}{ Son preference } \\
\hline & \multicolumn{3}{|c|}{ None/moderate } & \multicolumn{3}{|c|}{ Strong/moderate } \\
\hline & $\begin{array}{l}\text { No control } \\
\text { for pension } \\
\text { (1) }\end{array}$ & $\begin{array}{l}\text { Control } \\
\text { for pension } \\
\text { (2) }\end{array}$ & $\begin{array}{l}\text { (N) } \\
(3)\end{array}$ & $\begin{array}{l}\text { No control } \\
\text { for pension } \\
\text { (4) }\end{array}$ & $\begin{array}{l}\text { Control } \\
\text { for pension } \\
\text { (5) }\end{array}$ & $\begin{array}{l}\text { (N) } \\
(6)\end{array}$ \\
\hline Total sample & $.77^{\circ}$ & $.77^{*}$ & $(1,128)$ & $1.39^{*}$ & $1.33^{*}$ & $(1,631)$ \\
\hline Rural & $.55^{*}$ & $.46^{*}$ & (395) & $1.32^{*}$ & 1.18 & (686) \\
\hline Urban & $.76^{*}$ & .88 & (733) & $1.43^{*}$ & $1.41^{*}$ & (945) \\
\hline Illiterate & $.48^{*}$ & $.47^{*}$ & (235) & $1.39 t$ & 1.33 & (418) \\
\hline Primary education & .96 & .94 & (716) & $1.35^{*}$ & $1.28^{*}$ & $(1,010)$ \\
\hline Junior hight education & .52 & .54 & (177) & $1.45^{*}$ & $1.48^{*}$ & (203) \\
\hline Income $<4,000$ & $.42^{*}$ & $.40^{\circ}$ & (193) & $1.49^{*}$ & 1.39 & (342) \\
\hline Income 4,000-9,999 & .95 & .97 & (607) & $1.29^{*}$ & $1.24^{*}$ & (838) \\
\hline Income $10,000+$ & .58 & .60 & $(160)$ & 1.20 & 1.21 & (191) \\
\hline
\end{tabular}

NOTE: The regressions control for importance of continuing the family name, importance of having a son in the family (general), religiosity and filiality, emotional value of children, and rural/urban residence. Respondents' reactions to a hypothetical government pension were obtained from responses to the question: "If the government established a good program so that you would be paid a pension when you grew old. . . [how] ... important [would it be] to have a son in the family?" Their expected reliance was measured from responses to the question: "(lf you had sons) would you expect your son(s) to support you financially when old?" Sex-preference responses were collapsed from the Coombs IS scale to IS 1-4 (no son preference), IS 5 (moderate son preferencel, and IS 6-7 (strong son preference).

- Significant at twice standard error.

t Significant at 1.86 times standard error. 
standard errors of all the estimates. It suggests that the relationship between great/little support expectations and fertility preferences was strongest among the lower strata, and that the lower strata also demonstrated a possible effect of a pension on the relationship between expected reliance and son preference. These were the strata for which little or no old-age insurance existed aside from children.

\section{CONCLUSION}

This study has examined Philippine and Taiwanese women's expectations of relying on children for financial support when old: the level and distribution of expectations, their determinants or correlates, and their relation to several demographic and socioeconomic factors. Support of the elderly, be it through society-wide or intrafamily transfers, is an issue faced by all societies, and it may have important welfare and demographic consequences.

\section{Summary of findings}

Respondents in both the Philippines and Taiwan perceived considerable economic old-age security value in children. A sizable proportion of both samples mentioned old-age security when asked about the advantages of having children. The study revealed two major differences between the societies, however. In the Philippines a majority expected to rely only a little on children for financial support when old, whereas in Taiwan a majority expected to rely on children a great deal. Cultural, historical, and developmental factors may explain this difference. The second major difference was that, in the Philippines, respondents expected to rely approximately equally on sons and daughters for economic support when old whereas, in Taiwan, they expected to rely on sons much more than on daughters. This latter difference might be explained by the different traditional family systems in the Philippines and Taiwan. The former society has been bilineal whereas the latter has been patrilineal.

Support expectations were negatively related to standard indicators of socioeconomic status in both the Philippines and Taiwan. The important exceptions were that exposure to mass media and age had significant net relationships in Taiwan but not in the Philippines. The reasons are unknown.

Differences in socioeconomic status probably indicate several things. First, they indicate differences in prestige, power, and financial 
resources. The more, particularly financial, resources people expect to have in old age, the less they may expect to rely on children for financial support. Socioeconomic differences may also indicate differences in attitudes toward independence and family relations since each social group tends to share different socialization experiences. If people in higher strata tend to believe that family relationships do not include financial interdependencies, or that young children are to be provided for but adult children "have their own lives to lead," then one could assume that people in higher strata would expect to rely less than other people on children in old age.

The idea that attitudes had an important effect on support expectations was tested by a multivariate analysis that included socioeconomic and attitude measures. Although the measurement of relevant attitudes was limited, especially in the Philippines, in general the inclusion of attitude variables reduced the independent effect of socioeconomic characteristics on support expectations. Attitude variables also tended to have significant independent effects on support expectations in both countries.

The most important attitude measure was a scale of expectations of other economic help from children. A scale called "other economic help," this variable measured whether or not respondents ex pected children to help support their siblings' education or send part of their wages home when children began earning. Individuals' sense of personal efficacy had an independent effect on expected reliance on children in the Philippines. The Taiwan survey asked several additional questions about saving and self-sufficiency in old age, which proved to be significantly related to expected reliance on children for financial support in old age.

A fairly consistent difference emerged between countries in the size of the effects of the socioeconomic characteristics on support expectations. The socioeconomic effects tended to be smaller in the Philippines than in Taiwan, especially in the case of education. This finding could reflect the more rapid economic development that has occurred in Taiwan, possibly resulting in larger gaps between the social groups. Also noteworthy was the finding that, in the Philippines, urban/rural residence had no net relationship with whether or not an individual expected any old-age support from children.

There was clear support for the hypothesis that expected reliance on children for financial support when old would affect fertility 
preferences in both the Philippines and Taiwan. The effect appeared specific to higher-order parities: to four or more children in the Philippines and to wanting a fourth child in Taiwan. An attempted specification by socioeconomic group found that the old-age security effect was significant among lower strata but not among higher strata. However, the level of stratification below which there was an effect differed between the Philippines and Taiwan. The effect was significant only among the lowest strata in the Philippines whereas it was significant amiong all but the highest strata in Taiwan. This difference could be explained by several factors, including cultural background, recent rates of economic development, and sample size. Attempts at specifying the old-age security effect by social-psychological characteristics or by family orientations proved unsuccessful, perhaps because of the difficulty of creating comparable measures across societies.

Expected reliance on children for financial support in old age was related to sex preferences in Taiwan but not in the Philippines. This finding is probably explained by the difference in the functional value of daughters and sons in the two cultures. In Taiwan sons but not daughters have been expected to support elderly parents. In the Philippines, in contrast, both daughters and sons have been expected to support elderly parents.

A relationship between expected reliance on sons when old and son preference in Taiwan has implications for the modernization of the Chinese family, because both parental support and son preference have been central to the traditional Chinese family structure. This study found the two family orientations to be related to each other regardless of other elements of a patrilineal system, such as the importance of having a son to continue the family line. The findings supported the idea that a decline in expected reliance on sons might affect a decline in son preference. In contrast to the relationship between support expectations and fertility preferences, however, the relationship between support expectations and son preference did not appear to be affected by socioeconomic status in Taiwan, except to the extent that virtually everyone in the lower strata expected to rely on sons for at least a little financial support. The support-expectations -son-preference relationship among the upper strata appeared to reflect the relationship among the entire sample. There was some indication that the introduction of a "good" government pension 
might reduce the effect of support expectations on a strong son preference among rural, illiterate, and poor respondents.

\section{Policy implications}

In both societies respondents in the higher socioeconomic strata had lower expectations of relying on children than did lower socioeconomic respondents. Their lower expectations could become more typical of all socioeconomic groups in the future, because education is becoming more widely available and the attitudes of the middle class may diffuse downward over time. For whatever reasons, be they financial or attitudinal, such lower expectations imply the expectation of relying on financial sources other than children in old age. Presumably these sources would be pensions, personal savings, continued employment, or some combination of these.

It is improbable that continued employment at older ages will substitute for support from children, since modern retirement tends to be at younger rather than older ages (see C.K. Park, 1975). Nor can most "older" elderly (70+ years) be expected to support themselves by continued employment. It is more likely that personal savings, private pensions, or government social security systems will substitute for at least some financial assistance from children (see Palmore, 1975: chap. 6).

According to unpublished tabulations provided by Ronald Freedman (Population Studies Center, University of Michigan), in Taiwan there was an apparent shift between 1973 and 1980 from children to personal savings as the expected primary means of support in old age. Whereas 52 percent of a national sample of wives 15-44 years old expected to rely on children as their primary means of support in 1973 , this proportion declined to only 28 percent by 1980 . Over the same period the proportion expecting to rely on personal savings as the primary means of support increased from 41 to 61 percent. The proportion expecting primary support to come from pensions grew only from 8 to 12 percent of the sample. Yet to be able to rely primarily on personal savings requires an income considerably above subsistence level, trustworthy savings institutions, and faith that economic prosperity will continue. That incomes will be large enough to permit sufficient savings by more than a small proportion of the population in either the Philippines or Taiwan is open to question. 
Nor is there reason to assume that public old-age insurance schemes naturally arise from industrialization or even from a perceived need or desire for them. For instance, Japan, which is the only culturally nonWestern country to have completely modernized, appears to have a remarkably low level of welfare spending relative to other indicators of socioeconomic development (Wilensky, 1975:122); and public oldage welfare competes for limited funds with other government services such as education, housing, public health, and road building. Old-age provisions may have lower priority than other programs because the family has presumably cared for its elderly in the past and other needs may be more pressing.

Nor will the problematic financial aspect of old-age welfare schemes necessarily attenuate with increased prosperity. Even rich countries like the United States have problems financing comprehensive social security schemes. It is also unclear, given the average quality of nursing home care and present bureaucratic programs, that currently modernizing societies would want to repeat the experience of the West.

In a recent article Chan (1979) evaluated three possible insurance schemes in the Chinese context: (1) noncontributory public assistance, (2) social insurance including labor insurance, and (3) a provident fund. In his estimation the provident fund had the most promise for developing countries from the viewpoint of resource mobilization and population coverage. Provident funds require employees and employers to set aside a certain percentage of their wages into a government fund. This fund may cover various contingency needs of workers and their dependents such as disability, retirement, or death. Between acquiring the funds and paying them out, the fund can invest money in development schemes. In Singapore provident funds have been used to help pay for a massive rehousing of the population. By 1980 a majority of Singaporeans lived in and owned modern flats, which provided them with some security for retirement years (Yeh, 1975). The effect of such schemes on the relationship between parents and children is unclear. Potentially, parents are provided with some security from outside sources, which may be augmented by contributions from children.

Might a government pension scheme that partially substituted for the financial support of children help to reduce desired fertility? Expecting only a little economic support from children rather than a great deal of support has a dampening effect on fertility preferences. 
The effect is strongest among lower socioeconomic groups not yet covered by existing pension or social security programs, and it is specific to the preference for higher-order children.

The notion that expanding old-age insurance could be a viable antinatalist policy has been criticized for several reasons. For one, the idea is highly conjectural. However, a cross-sectional study of developing countries found pension coverage and benefit level to be related to lower fertility five years later (Entwisle, 1979; Entwisle and Winegarden, forthcoming; see also Nugent and Gillaspy, 1983). ${ }^{10}$ A second criticism is that the antinatalist policy would be indirect and very expensive. The cost-effectiveness of such a program might not be as high as more direct attempts to reduce population growth, such as family planning programs or the employment of women. But social insurance schemes can contribute to social and economic development as well as be antinatalist (Singer, 1968; Shome, 1978; Lapman, 1968); and they need not compete with other antinatalist policies. In short, the idea that a pension or provident fund scheme could simultaneously have antinatalist effects and positive economic-development effects deserves more serious and in-depth analysis than it has been given up to now.

The VOC study produced tentative evidence that the introduction of a pension might weaken the effect of expected reliance on son preference in Taiwan among rural respondents and respondents with low incomes. Practically no other empirical evidence exists on this topic that I know of, but the idea that introducing an old-age pension might reduce son preference among individuals presently not covered by such a pension warrants further inquiry.

\section{Study limitations and directions for future research}

The present study had three main limitations.

First, it addressed theoretical issues pertinent to all or most developing countries but studied only two countries, the Philippines and Taiwan. It is tempting to generalize the findings to other countries, and undoubtedly some generalization is valid. But even between

10. The reasons for the development of pension and old-age welfare programs are unclear. Family, economic, and political explanations have all been offered (Wilensky and Lebeaux, 1958; Cutright, 1965; Rimlinger, 1971 ; Wilensky, 1975). Nor is it clear that such historical explanations, even if we knew what they were, would be applicable to presently modernizing countries. 
Taiwan and the Philippines, differences in cultural background, history, and recent economic experience may be of possible importance for the old-age economic security value of children. The study found that the relationship between old-age support expectations and the strength of son preference was specific to Taiwan. Clearly, there is need to study other countries before one can be truly confident about the generalizability of most of the study findings.

The second major limitation of the study was that it investigated the old-age economic security value of children at only one time, using cross-sectional survey data. Yet the root of much of the theoretical interest in this value of children stems from the idea that the value changes with economic development, specifically that responsibility for old-age support tends to be focused on family members in traditional societies but tends to be diffused among an entire workingage generation in modern societies. I suggested that at times socioeconomic differentials help indicate directions of change; that is, in societies undergoing rapid socioeconomic development, attitudes held by a well-educated group at one time might become more common among a less educated group at a future time. If couples' support expectations of children are lower among higher socioeconomic status groups than among lower status groups, it could indicate that support expectations are declining throughout a society. Longitudinal analysis has the obvious advantage of addressing issues of change directly.

A third limitation of the study was that it did not have good measures for all of the factors that could be important determinants of expected reliance on children or that needed to be controlled when estimating a relationship between expected reliance on children and fertility preferences or son preference. Especially for the Philippines, the number of attitudes measured concerning old-age were quite limited. In establishing independent relationships between support expectations and fertility preferences or son preference, it would also have been more satisfying to control for a better measure of other economic values of children and a better measure of the fear of child mortality. ${ }^{11}$ This comment is made not to undermine the potential

11. The control for other economic values of children did not distinguish well between people who expected a "great deal" or "only a lit tle" economic help of other kinds, yet it was just this distinction that proved important for the old-age support variable. Fear of a child death had to be measured approximately by whether or not the respondent had ever experienced an infant or child death. 
usefulness of the study findings, but to alert researchers to the need for such measures in future studies.

In conclusion, this study has contributed to our understanding of the old-age economic security value of children, its level and distribution, its relation to socioeconomic characteristics and attitudes, its substantial effect on fertility preferences, and, in a traditionally patrilineal society, its significant relationship with son preference. The hypotheses addressed here need further exploration with better data sets, both for additional time periods and for additional countries. The hypotheses tested are only a subset of those surrounding the interdependence of parents and children and its relation to demographic phenomena. The efforts made herein will, I hope, provide a stepping stone for such inquiry. 
APPENDIX: CONSTRUCTION OF SELECTED VARIABLES

The construction of variables that may be of particular interest to the reader is reported below. For details regarding other variables used in the study, see De Vos (1982) or write to the author.

\section{Residence}

The survey initially determined respondents' residence as:

Philippines: urban, barangay (town center), or barrio (rural).

Taiwan: urban or rural.

The survey also asked about the respondent's residential background:

(If rural) "Have you ever lived in a large town or city?"

(If urban) "Have you ever lived on a farm or in the country?" The initial determination and answers to the subsequent questions were used to form the residence variable used in the study.

Besides distinguishing between urban, barangay, and barrio residents, the Philippine variable also classifies the backgrounds of barangay residents: urban, barangay with some urban experience, barangay with no urban experience, and rural barrio.

In Taiwan, the variable distinguishes people who always lived in an urban area from those who had always lived in a rural area and from those who had some experience living in both areas: urban, mixed (rural resident with some city experience or urban resident with some rural experience), and rural.

\section{Social-psychological orientations}

The VOC survey asked respondents to agree or disagree with four social-psychological statements, three of which could be combined into a single scale called "personal efficacy." Responses to the four statements were coded similarly.

1a. Philippines: "Getting ahead in life is mostly a matter of luck." LUCK

1b. Taiwan: "To you, getting what you want has little or nothing to do with luck." LUCK

2. "It is not always wise to plan too far ahead because many things turn out to be a matter of good or bad fortune anyway." PLAN

3. "Many times you feel that you have little influence over the things that happen to you." INFL

4. "When you make plans, you are almost certain you can make them work." CRTN 


\section{Personal efficacy}

Responses to the first three statements-LUCK, PLAN, INF-were scaled into a four-point scale (one point for each strong agree answer) measuring personal efficacy. Responses to the fourth, CRTN, statement were not related to any thing else and were dropped from the analysis.

\section{Fertility preferences (Coombs IN)}

Coombs IN, as a measure of fertility preferences, does not measure number of children preferred. However, it overcomes several disadvantages inherent in previously devised measures of fertility preferences. It uses probes to measure whether a respondent would prefer more or fewer children than her first stated preference. Second, the measure is theoretically independent of sex preference, al though it may be related to sex preference empirically. Third, Coombs IN is more independent of actual fertility than are measures based on current parity. Fourth, Coombs IN tends to have smaller standard errors than other measures of fertility preferences.

The scale is constructed from answers to an initial question and subsequent probes that depend on the answer to the first question:

"If you were to start your family all over again, and you knew that you would have an equal number of boys and girls, how many children in all would you most like to have-no children at all, or one boy and one girl, two boys and two girls, or three boys and three girls?"

"If you didn't have boy(s) and have boy(s) and girl(s) or girl(s), would you rather no children)?" boy(s) and $\operatorname{girl}(\mathrm{s})$ (or

The answers are "unfolded" into a decision tree in which the dash distinguishes the order of questioning:

1. none

2. 1 each-none

3. 1 each-2 each-none

4. 1 each-2 each-3 each

2 each-1 each-none-

5. 2 each-1 each-3 each

6. 2 each-3 each

7. 3 each 


\section{Sex preferences}

The measures of sex preference used here are derived from the Coombs IS measure of individual preferences. The relatively new measure represents an important improvement over past measures of sex preference because it measures individual attitudes independently of fertility preferences. It is also cross-cultural comparable (Coombs, 1975). For this study, the final trichotomous variables measuring sex preference differ for each country because many Filipinos prefer daughters as well as sons whereas most Taiwan respondents preferred sons only. The final variables measure strength of sex preference.

Coombs IS

"If you were to have exactly three children altogether, how many would you want to be boys and how many girls?"

"If you didn't have have boy(s) and boy(s) and girl(s) or girl(s), would you rather boy(s) and girl(s)?"

Answers to the questions form a tree in which the dash distinguishes the order of questioning.

1. 3 girls

2. 2 girls and 1 boy -3 girls

3. 2 girls and 1 boy -1 girl and 2 boys -3 girls

4. 2 girls and 1 boy -1 girl and 2 boys -3 boys

1 girl and 2 boys -2 girls and 1 boy -3 girls

5. 1 girl and 2 boys -2 girls and 1 boy -3 boys

6. 1 girl and 2 boys -3 boys

7. 3 boys

Strength of Sex Preference (Philippines)

1. None (IS 4)

2. Moderate (IS 3,5)

3. Strong (IS $1,2,6,7$ )

Son Preference (Taiwan)

1. None (IS 1-4)

2. Moderate (IS 5)

3. Strong (IS 6-7) 


\section{Other economic help from children}

These questions are similar to the questions on expected reliance on sons or daughters for support when old, except that answers do not distinguish between expecting "only a little" or "a great deal" of help.

"(If you had sons) would you expect your sons to:

a. Give part of their salary to you when they begin working?

b. Help support younger brothers or sisters through school?" "(If you had daughters) would you expect your daughters to:

c. Give part of their salary to you when they begin working?

d. Help support younger brothers or sisters through school?" The answers are coded as:

1. No

2. Depends

3. Yes

Responses of "no" to all the questions were put into the "no" category. Responses of "it depends" to any of the questions were put into the "depends" category. Responses of "yes" to all four questions were placed into the third, "yes" category. In the Philippines, the "no" and "depends" categories were combined because there were so few responses in either category. In Taiwan, the original threecategory variable was retained. 


\section{REFERENCES}

Arnold, Fred, Rodolfo A. Bulatao, Chalio Buripakdi, Betty Jamie Chung, James T. Fawcett, Toshio Iritani, Sung J in Lee, and Tsong-Shien Wu

1975 The Value of Children: A Cross-National Study, Vol. 1, Introduction and Comparative Analysis. Honolulu: East-West Population Institute, East-West Center.

Baker, Hugh

1979

Chinese Family and Kinship. New York: Columbia University Press.

Barnes, Harry Elmer

1952 Society in Transition, 2nd Edition. New York: Prentice Hall.

Bulatao, Rodolfo A.

1975 Philippines. Vol. 2, The Value of Children: A Cross-National Study. Honolulu: East-West Population Institute, East-West Center.

1979a Further Evidence of the Transition in the Value of Children. Paper No. 60-B. Honolulu: East-West Population Institute, East-West Center.

1979b On the Nature of the Transition in the Value of Children. Paper No. 60-A. Honolulu: East-West Population Instilute, East-West Center.

1981 Values and disvalues of children in successive childbearing decisions. Demography 18(1):1-26.

Caldwell, John C.

1982 Theory of Fertility Decline. New York: Academic Press.

Chaffee, Frederick H, George I. Aurell, Helen S. Barth, Ann S. Cort, John H. Domgrowski, Vincent J. Fasano, and John O. Weaver

1969 Area Handbook of the Republic of China. Washington, D.C.: U.S. Government Printing Office.

Chan, Gordon Hon-Sheng

An assessment of the social security system in three Chinese societies: Hong Kong, Singapore and Taiwan. Proceedings of the National Science Council 3(1):116-24. Taipei: National Science Council.

Chen, Lincoln C., Emdadul Hug, and Stan D'Souza

1981 Sex bias in the fanily allocation of food and health care in rural Bangladesh. Population and Development Review 7(1):55-70. 
Coombs, Lolagene

1975 Are cross-cultural preference comparisons possible? A measurement-theoretic approach. IUSSP Paper No. 5. Liège: International Union for the Scientific Study of Population.

1977 Leveis of reliability in fertility survey data. Studies in Family Planning 8(9):218-32.

1980 Economic factors in fertility decisions: The role of costs and benefils. Academia Economic Papers 8(2):89-122.

Coombs, Lolagene, and Te-Hsiung Sun

1981 Changes in familial values in a developing society: A decade of change in Taiwan. Social Forces 59(4):1229-55.

Cowgill, Donald O., and Lowell D. Holmes, eds.

1972 Aging and Modernization. New York: Appleton-Century-Crofts.

Cutright, Phillips

1965 Political structure, economic development, and national social security programs. American Journal of Sociologv 70:537-50.

De Vos, Susan

1982 The economic old age security value of children in the Philippines and Taiwan in the middle 1970's. Unpublished Ph.D. dissertation, Department of Sociology, The University of Michigan, Ann Arbor, Michigan.

1983 An old age security incentive for children: Evidence from the Philippines and Taiwan. Center for Demography and Ecology Working Paper 83-21. Madison, Wisconsin: University of Wisconsin.

Djang, T.K.

1977 Industry and labor in Taiwan. In Labor Insurance, Chapt. 12. Monograph No. 10. Taipei: The Institute of Economics, Academia Sinica Nankang.

Entwisle, Barbara

1979 Education, pension programs, and fertility: A cross-national investigation, with special reference to the potential held by education and pension programs as fertility reduction policies. Unpublished Ph.D. dissertation, Department of Suciology, Brown University.

Entwisle, Barbara, and C.R Winegarden

Forth- Fcrtility and pension programs in LDCs: A model of mutual coming reinforcement. Economic Development and Culture Change. 
Far Eastem Economic Review

1981 Asia Yearbook 1981. Hong Kong.

Freedman, Ronald, and Lolagene Coombs

1974 . Cross-Cultural Comparisons: Data on Two Factors in Fertility Behavior. New York: The Population Council.

Freedman, Ronald, Albert Hermalin, Te Hsiung Sun, and Ke Chih Liu

1980 Factors related to Taiwan's fertility decline: A review of the evidence. Taiwan Population Studies Working Paper No. 44. Ann Arbor: Population Studies Center, The University of Michigan.

Goldberg, David

1975 Socioeconomic theory and differential fertility: The case of the LDCs. Social Forces 54:84-106.

Goldscheider, Calvin

1971 Population, Modernization, and Social Structure Boston: Lit tle, Brown \& Co.

Goode, William

1970 World Revolution and Family Patterns, 2nd Edition. New York: The Free Press.

Hoffman, Lois W.

1972 A psychological perspective on the value of children to parents: Concepts and measures. In James T. Fawcett (ed.), The Satisfactions and Costs of Children: Theories, Concepts, Methods, pp. 27-56. Honolulu: East-West Population Institute, East.West Center.

Inkeles, Alex, and David H. Smith

1974 Becoming Modern: Individual Change in Six Developing Countries. Cambridge, Massachuset ts: Harvard University Press.

Jones, Gavin W.

1977 Economic and social supports of high fertility. In Lado T. Ruzicka (ed.), The Economic and Social Supports for High Fertility, pp. 3-47. Canberra: Australian National University.

Kagitcibasi, Cigdem

1982 Old-age security value of children: Cross-national socioeconomic evidence. Joumal of Cross-Cultural Psychology 13(1):29-42. 
Kobayashi, Kazumasa

1977 Attitudes towards children and parents. In Fertility and Familv Planning in Japan, Chapt. 6. Tokyo: Japanese Organization for International Cooperation in Family Planning.

Lampman, Robert J.

1968 The investment of social security reserves and development problems: The Philippines as a case history. In Everett Kassalow (ed.), The Role of Social Security in Economic Development. Social Security Administration Research Report No. 27. Washington, D.C.: U.S. Government Printing Office.

Lorimer, Frank

1954 Culture and Human Fertility. Paris: Unesco.

Mueller, Eva

1976

The economic value of children in peasant agriculture. In Ronald $G$. Ridker (ed.), Population and Development, Chapt. 4. Baltimore: Johns Hopkins Press.

Nag, Moni, ed.

1975 Economic Cost and Value of Children in Javanese, Nepalese and Peruvian Villages. New York: International Institute for the Study of Human Reproduction, Columbia University.

Neher, Phillip

1971 Peasants, procreation and pensions. American Economic Review 61:380-89.

Notestein, Frank W.

1945 Population: The long view. In Theodore W. Schultz (ed.), Food for the World, pp. 36-57. Chicago: University of Chicago Press.

- Nugent. Jeffrey B., and R. Thomas Gillaspy

1983 Old age pensions and fertility in rural areas of less developed countries: Some evidence from Mexico. Economic Development and Cultural Change 31(4):809-29.

O'Connell, James

1976 The concept of modernization. In Cyril E. Black (ed.), Comparative Modemization. New York: The Free Press.

Palmore, Erdman

1975

The Honorable Elders: A Cross-Cultural Analysis of Aging in Japan.

Durham, North Carolina: Duke University Press. 
Park, Chai Bin

1978 The fourth Korean child: The effect of son preference on subsequent fertility. Joumal of Biosocial Science 3:377-87.

Park, Chong Kee

1975 Economic and social changes and their implications for social security in the Republic of Korea. International Social Security Review 28(3):242-55.

Poffenberger, T., and S.B. Poffenberger

1973 The social psychology of fertility behavior in a village in India. In James T. Fawcett (ed.), Psychological Perspectives on Population, pp. 135-62. New York: Basic Books.

Polgar, Steven

1971 Culture history and population dynamics. In Steven Polgar (ed.), Culture and Population, pp. 3-10. New York: Schenkman Publishing Company, Inc.

Rimlinger, Gaston

1971 Welfare Policy and Industrialization in Europe, America, and Russia. New York: John Wiley \& Sons, Inc.

Shome, Parthasarathi

1978 Social security as a mobilizer of savings: The experience of Malaysia. International Social Security Review 31:58-70.

Simmons, Leo W.

1960 Aging in preindust rial societies. In Clark Tibbitts (ed.), Handbook of Social Gerontology, pp. 62-91. Chicago: University of Chicago Press.

Singer, H.W.

1968 Social factors in development: An overview with special emphasis on social security. In Everett M. Kassalow (ed.), The Role of Social Security in Economic Development. Social Security Administration Research Report No. 27. Washington, D.C.: U.S. Government Printing Office.

Sun, Te-Hsiung

1968 Socio-structural analysis of fertility differentials in Taiwan. Unpublished Ph.D. dissertation, Department of Sociology, The University of Michigan.

United Nations

1973 The Determinants and Consequences of Population Trends, Vol. 1. New York. 
Vlassoff, M.

1982 Economic utility of children and fertility in rural India. Population Studies 36(1):45-60.

Vlassoff, M., and Carol Vlassoff

1980 " Old age security and the utility of children in rural India. Population Studies 34(3): 487-99.

Vreeland, Nena, Geoffrey B. Hurwitz, Peter Just, Philip W. Maeller, and R.S.

Shinn

1979

Area Handbook for the Philippines Washington, D.C.: U.S. Government Printing Office.

Wilensky, Harold

1975 The Welfare State and Equality: Structural and Ideological Roots of Public Expenditures Berkeley: University of California Press.

Wilensky, Harold L., and Charles N. Lebeaux

1958 Industrial Society and Social Welfare. New York: Russell Sage Foundation.

Williamson, Nancy E.

1976 Sons or Daughters: A Cross-Cultural Survey of Parental Preferences. Beverly Hills: Sage Publishers.

Wil̀is, Robert J.

1981 The old age security hypothesis and population growth. In Thomas K. Burch (ed.), Demographic Behavior: Interdisciplinary Perspectives. Boulder, Colorado: Westview Press.

World Bank, The

$1980 \quad$ World Tables, 2nd edition. Baltimore: The Johns Hopkins University Press.

Wu, Tsong-Shien

1977 Taiwan. Vol. 5, The Value of Children: A Cross-National Study. Honolulu: East-West Population Institute, East.West Center.

Yeh, Stephen H.K., ed.

1975 Public Housing in Singopore: A Multi-Disciplinary Study. Singapore: Singapore University Press.

Yu, Elena, and William T. Liu

1980 Fertility and Kinship in the Philippines. South Bend, Indiana: University of Notre Dame Press. 
CURRENT ST UDIES ON THE VALUE OF CHILDREN is a sUbseries of PAPERS OF THE EAST-WEST POPULATION INSTITUTE. It presents analyses of data from the Value of Children project, a cross-national study of parents' perceptions of the satisfactions and costs of children, and findings from similar studies.

All papers in Current Studies will be assigned the number 60 , to indicate that they are part of Papers of the East-West Population Institute. The serial number for each subseries paper, however, will include a letter suffix (A, B, etc.) designating its sequence in the subseries.

Editor: James T. Fawcett

\section{PREVIOUS PAPERS IN THE SUBSERIES}

60-A On the nature of the transition in the value of children, by Rodolfo A. Bulatao, March $1979, x v i+104$ pp.

60-B Further evidence of the transition in the value of children, by Rodolfo A. Bulatao, November 1979 , viii +84 pp.

60-C The value of children to Australian, Greek, and Italian parents in Sydney, by Victor J. Callan, December 1980 , viii +60 pp.

60-D Two are not enough: the value of children to Javanese and Sundanese parents, by Russell K. Darroch, Paul A. Meyer, and Masri Singarimbun, February 1981, viii + $86 \mathrm{pp}$.

60-E The changing value of children in Turkey, by Cigdem Kagitcibasi, June 1982, viii + $100 \mathrm{pp}$.

60-F Influences on childbearing intentions across the fertility career: demographic and socioeconomic factors and the value of children, by Rodolfo A. Bulatao and James T. Fawcett, June $1983, x+152$ pp. 
THE EAST-WEST CENTER is an educational institution established in Hawaii in 1960 by the United States Congress. The Center's mandate is "to promote better relations and understanding among the nations of Asia, the Pacific, and the United States through cooperative study, training, and research."

Each year nearly 2,000 graduate students, scholars, professionals in business and government, and visiting specialists engage in research with the Center's international staff on major issues and problems facing the Asian and Pacific region. Since 1960 , more than 30,000 men and women from the region have participated in the Center's cooperative programs.

The Center's research and educational activities are conducted in four institutesCulture and Communication, Environment and Policy, Population, and Resource Systems-and in its Pacific Islands Development Program, Open Grants, and Centerwide Programs.

Although principal funding continues to come from the U.S. Congress, more than 20 Asian and Pacific governments, as well as private agencies and corporations, have provided contributions for program support. The East-West Center is a public, nonprofit corporation with an international board of governors.

THE EAST-WEST POPULATION INSTITUTE, established as a unit of the East-West Center in 1969 with the assistance of a grant from the Agency for International Development, carries out multidisciplinary research, training, and related activities in the field of population, placing emphasis on economic, social, psychological, and environmental aspects of population problems in Asia, the Pacific, and the United States. 